\title{
Isolation and Identification of Unique Arsenotolerant Exiguobacterium indicum DSAM62 from Arsenic Rich Environment
}

\author{
Debanjana Sengupta ${ }^{1, *}$, Siddhartha Chakraborty ${ }^{1}$, Sudeshna Shyam Choudhury $^{1}$, Sayak Ganguli $^{2}$, \\ Arup Kumar Mitra ${ }^{1}$
}

${ }^{1}$ Department of Microbiology, St. Xavier's College (Autonomous), Kolkata, India

${ }^{2}$ Department of Biotechnology, St. Xavier's College (Autonomous), Kolkata, India

Received March 12, 2020; Revised April 10, 2020; Accepted April 27, 2020

Copyright $\mathrm{C} 2020$ by authors, all rights reserved. Authors agree that this article remains permanently open access under the terms of the Creative Commons Attribution License 4.0 International License

\begin{abstract}
Arsenic infiltration via bio-geological and anthropogenic mean's has been a global concern in the developing countries due to the severe toxic effects of the compound which leaches to the ecological niche. Herein, we report one such arsenotolerant bacteria isolated from a contaminated soil collected from a district in West Bengal (India), where an arsenic concentration of the soil sample was found to be $0.51 \mathrm{mg} / \mathrm{kg}$. In the present study, several bacteria were isolated from the soil sample, out of which $\mathrm{LD}_{50}$ value of arsenic for the novel tolerant bacteria was found to be $500 \mathrm{mg}$./ 1 which was also determined by INT assay. The efficacy of arsenate uptake by this bacterium was $52.20 \%$ from its respective $\mathrm{LD}_{50}$ concentration. After 16S rDNA sequencing, the bacteria showed 99\% similarity with Exiguobacterium indicum based on nucleotide homology and meta-phylogenetic analysis. LCMS FAME revealed that the unique fatty acids were monosaturated C:10:03 OH (0.53\%), C12:1 (0.16\%), C11:03 OH (0.38\%), terminally branched Anteiso C14:0 (0.74\%), monosaturatedC15:1w5C, monosaturatedC16:0 N Alcohol, Anteiso 16:0 (0.36\%), Iso- C16:0 3OH (0.33\%), Iso- C18:1 $\mathrm{H}(0.25 \%), \mathrm{C} 18: 3 \mathrm{w} 6 \mathrm{C}(6,9,12)(0.53 \%), \mathrm{C} 18: 12 \mathrm{OH}$ $(0.52 \%)$, which lead us to conclude that the bacteria was a new and unique bacterial strain. So, on the basis of FAME analysis, the unique bacteria were named as Exiguobacterium indicum Strain DSAM62, which can be used as a potential bio accumulator in agricultural fields for bioremediation of arsenic. The fully annotated sequence of the genome and the plasmid of the novel strain revealing key regulatory genes were also investigated and results can be correlated with this tolerant behavior. The annotated sequence was submitted to NCBI genome database which currently having an accession number of PRJNA555453.
\end{abstract}

Keywords Exiguobacterium indicum Strain DSAM 62,
Arsenic, Tolerance, Uptake

\section{Introduction}

Arsenic is a toxic element of the environment and it is a member of group $\mathrm{V}$ of the periodic table. So, it is classified as a heavy metal (Wackett, 2004). It mainly exists in the nature in two forms, the predominant pentavalent arsenic As [V] and trivalent arsenic As [III] (Cullen and Reimer, 1989) because arsenate As [V] is immobilized in the solid phase and arsenite As [III] primarily exists as uncharged $\mathrm{H}_{3} \mathrm{As}_{3}^{0}{ }_{3}$ with the pKa value of 9.2. Less toxic methylated form of arsenic dimethylarsinic (DMA) and monomethylarsonic (MMA) are generated by microorganisms under oxidizing conditions (Wang et al., 2007). Groundwater contamination with bioavailable arsenic has been found in West-Bengal, India and Bangladesh (Smith et al., 2002) as a direct result of irrigation in crop fields by contaminated water. Rice grains are also affected by bioaccumulation of arsenic (Meharg and Rahman, 2003) which exhibits the most common route of arsenic poisoning through food chain (Chowdhury, 2004) and causes skin cancer, liver and lung cancers (Wang et al., 2001). The most common way for heavy metal removal techniques from industrial effluents are chemical precipitation, chemical oxidation or reduction, ion exchange, filtration, electrochemical treatment, reverse osmosis, membrane technologies and evaporation recovery (Ahluwalia and Goyal, 2007). These methods are expensive and have some drawbacks in the higher concentration of heavy metal removal (Nourbakhsh et al., 1994). Therefore, innovative, low-cost and eco-friendly 
microbes involving bioremediation techniques for heavy metal mitigation from the industrial sludge are developed. Bacteria can absorb, adsorb, chelate and biochemically modify arsenic species into much less toxic forms of reduced arsenic with the help of proteins helping in metal binding and modification, these activities are regulated by the inducible gene expression upon arsenic stress. The present study involves the isolation, characterization, arsenic tolerance studies, uptake ability and identification of a novel bacteria isolated from the arsenic contaminated soil from a rural area of West- Bengal.

\section{Materials and Methods}

\subsection{Arsenic Content Analysis of Soil Sample by ICP-OES}

Arsenic concentration of the collected soil sample from Shyamnagar was measured by ICP-OES after preparing the soil sample by wet digestion method (USEPA, 1996). 2 gm. of soil sample was mixed with $5 \mathrm{ml}$. of $69 \% \mathrm{HNO}_{3}$ in 100 $\mathrm{ml}$ Borosil glass conical flask and it was incubated for overnight. After the incubation the sample was kept in block tubes and the block tubes were kept in the Block Digester (AIM 600 Digestion System, Australia). Arsenic content of the soil sample was analyzed by Thermo Scientific, Model No. ICAP 6000 at $193.759 \mathrm{~nm}$ wavelength in UV region.

\subsection{Characterization of the Collected Soil and Water Samples}

The soil sample was collected from paddy rhizospheric soil from Shyamnagar. Then, the deionized water was added into the soil in 1:10 ratio. Then the mixtures were filtered and $\mathrm{pH}, \mathrm{EC}$ content and specific gravity of all the collected samples were measured.

\subsection{Bacterial Isolation by Serial Dilution Method}

The colloidal soil sample was measured up to $1 \mathrm{ml}$ and dissolved in $9 \mathrm{ml}$ of sterile, deionized water to prepare a dilution of $10^{-1}$. From this, $10^{-2}$ and $10^{-4}$ dilutions were prepared in sterile, de-ionized water. The $10^{-2}$ and $10^{-4}$ dilutions were used for pour-plating with fresh, sterile Nutrient Agar (HiMedia) media to obtain isolated bacterial colonies. For this, $0.2 \mathrm{ml}$ of sample aliquots were placed in sterile petri-plates and to it, the nutrient agar (HiMedia) was added and swirled gently. After solidification, the plates were incubated for about 24 hours, at $37^{\circ} \mathrm{C}$. Numerous colonies were obtained in each plate. Few colonies were selected on the basis of their frequency at random for further studies, i.e., morphological and biochemical characterization.

\subsection{Biochemical Characterization of the Isolated Bacteria}

Since bacterial organisms are similar in morphological and cultural characteristics, four biochemical tests are used to differentiate between these bacteria. InVic and Sugar Utilization test were performed for the identification of the bacteria at preliminary stage.

For indole test, the bacterial strains were inoculated in tryptophan broth and they were incubated at $37^{\circ} \mathrm{C}$ for 24 hours. After 24 hours of incubation, $0.5 \mathrm{ml}$ of Kovac's reagent was added to it, without shaking. Development of reddish ring was taken as a positive result.

For methyl red test, 48 hours old bacterial cultures in dextrose phosphate broth were taken and about $0.5 \mathrm{ml}$ methyl red indicator was added to it, followed by shaking. Development of red coloration was taken as a positive result.

The bacterial strains were inoculated in dextrose phosphate broth for Voges-Proskauer test and they were incubated at $37^{\circ} \mathrm{C}$ in BOD Incubator Shaker for 48 hours old cultures in dextrose phosphate broth were taken and to it about $0.6 \mathrm{ml}$ Barritt's reagent was added with vigorous shaking. Development of copperish red color was considered as a positive result.

For citrate utilization test, the bacterial strains were inoculated in Simmon's Citrate Agar (HiMedia) media and they were incubated at $37^{\circ} \mathrm{C}$ for 24 hours. After 24 hours of incubation, the change in color of media from green to blue was taken as a positive result.

For chrome agar test, $24 \mathrm{hrs}$ old cultures in Hi chrome agar (HiMedia) media were taken and the characteristic color of the respective cultures was observed.

For sugar utilization Test, each tube containing TSI agar (HiMedia) was taken. Small amount of the experimental bacteria from fresh culture was inoculated by using of the sterile technique into the tubes by means of slant and stab inoculation method with an inoculating loop. Then, the tubes were then incubated at $37^{\circ} \mathrm{C}$ for $24-48$ hours in BOD Incubator. After 24-48 hours the color of both the stab and slant of agar slant cultures were observed.

\subsection{Arsenic Tolerance Study}

The bacterial cultures were inoculated into sterilized 30 $\mathrm{ml}$. of nutrient broth supplemented with increasing concentrations of arsenic [As(v)] like $10 \mathrm{mg} . / 1,30 \mathrm{mg} . / 1,50$ mg./1, $70 \mathrm{mg} . / 1,80 \mathrm{mg} . / 1,100 \mathrm{mg} . / 1,200 \mathrm{mg} . / 1,300 \mathrm{mg} . / 1$, $500 \mathrm{mg} . / \mathrm{l} .800 \mathrm{mg} . / \mathrm{l}$ and $1000 \mathrm{mg} . / \mathrm{l}$ and they were incubated at $37^{\circ} \mathrm{C}$ for 24 hours and 48 hours. After the incubation, $\mathrm{OD}_{580}$ values were taken for each bacterial sample to find the $\mathrm{LD}_{50}$ value and the maximum arsenic tolerance level of each bacterial strain.

\subsection{Arsenic Analysis by ICP-OES}

The bacterial cultures were centrifuged (Remi Cold 
Centrifuge Machine, Model No.C-24) and the supernatants were taken for acid digestion. Then the samples were prepared with $69 \% \mathrm{w} / \mathrm{v} \mathrm{HNO}_{3}$, using de-ionized water. Acidification to $\mathrm{pH}$ less than 2 was done 16 hours before the ICP-OES analysis. Necessary dilutions were made if the arsenic content exceeded the calibration standards. The nebulizer flow and plasma power were optimized (i.e., the plasma power adjusted between $1300-1400 \mathrm{~W}$ ) using a 5 mg./l arsenic solution. Next, the nebulizer flow was incrementally adjusted between 0.90 and $0.60 \mathrm{~L} / \mathrm{min}$ for radial and axial plasmas, in that order. After observing change in intensity, the best flow was established and used for the analyses. The most sensitive lines for arsenic lie in the UV region (193.759 $\mathrm{nm}$.) and an appropriate spectrophotometer (Thermo Scientific, Model No. ICAP 6000 Duo) were used. For correlating the results, the arsenic standard is diluted with $1 \%$ ultrapure $\mathrm{HNO}_{3}$ and analyzed on the instrument. After the run, the peaks and baselines are reset, the blanks are identified as global blanks, any interfering elements are identified for subsequent subtraction.

\subsection{Cell viability Test Using INT Assay}

The bacteria was grown in tryptic soy broth (HiMedia) with $500 \mathrm{mg} . / 1,300 \mathrm{mg} . / 1$ arsenic As (V) and without arsenic $\mathrm{As}(\mathrm{V})$ at $37^{\circ} \mathrm{C}$ for 24 hours at BOD Incubator Shaker. After the incubation, $100 \mu$ l. of the inoculums were inoculated in $3 \mathrm{ml}$. of $30 \%$ TSB containing $0.5 \mathrm{mg} . / \mathrm{ml}$ of 2-(4-Iodophenyl)-3-(4-nitrophenyl)-5-phenyl-2H-tetrazoli um chloride (INT) (SRL). Then it was incubated for 30 minutes at $37^{\circ} \mathrm{C}$ in BOD Incubator Shaker at $40 \mathrm{rpm}$ shaking speed. After the incubation the supernatant was separated and removed by centrifugation and $1 \mathrm{ml}$. of Dimethyl Sulfoxide (DMSO) (Merck) was added to each tube. The cell viability was quantified by measuring the absorbance at $490 \mathrm{~nm}$ wavelength in UV-Visible Spectrophotometer (Optizen) using DMSO as a blank (Steifel, et al., 2016).

\subsection{SEM-EDX}

To study the effect of arsenic on cellular morphology of $\mathrm{S} 6 \mathrm{C} 2$ bacteria, $1 \%$ inoculum was added into LB broth containing $\mathrm{LD}_{50}$ concentration of arsenic $[500 \mathrm{mg} . / 1$ of $\mathrm{As}(\mathrm{V})]$ and without arsenic (control) and incubated at $37^{\circ} \mathrm{C}$ in BOD Incubator Shaker incubator (100 rpm). Samples were harvested at mid- log phase and the samples were prepared for SEM and EDX according to De et al. (2008) and Daware and Gade, (2015). Following incubation, both control and arsenic stressed bacterial cells were harvested by centrifugation at $6,000 \mathrm{~g}$ for $10 \mathrm{~min}, 4^{\circ} \mathrm{C}$. The pelleted cells were washed twice with $0.1 \mathrm{M}$ potassium phosphate buffer solution (PBS; pH 7.2) and fixed overnight in $2.5 \%$ glutaraldehyde in $0.1 \mathrm{M}$ PBS at $8^{\circ} \mathrm{C}$. The cells were washed twice again with PBS. The cells were dehydrated through a series of different concentrations (from $30 \%$ to absolute) 1 $\mathrm{ml}$. of ethanol at $10,000 \mathrm{rpm}$ for 2 minutes. Finally, the pellet was dissolved in $200 \mu \mathrm{l}$ of $100 \%$ ethanol concentration for half an hour. Finally, $2 \mu \mathrm{l}$ of each sample was placed on $1 \mathrm{~mm}$ clean and grease free mini round glass cover slips. The glass cover slips were coated with platinum and examined under SEM with the acceleration voltage of $20 \mathrm{kV}$ (Zeiss Evo 18 Special Edition). Energy dispersive $\mathrm{x}$-ray spectroscopy (EDS) (Zeiss Evo 18 Special Edition) was performed to detect the presence of arsenic over cell surface.

\subsubsection{Identification of Bacteria by $16 \mathrm{~S}$ rDNA Sequencing}

According to Paul et al., 2015, DNA was isolated from $\mathrm{S} 6 \mathrm{C} 2$ bacteria. Its quality was evaluated on $1.0 \%$ Agarose Gel, a single band of high-molecular weight DNA has been observed. Fragment of 16S rDNA gene was amplified by $27 \mathrm{~F}$ and $1492 \mathrm{R}$ primers. A single discrete PCR amplicon band of $1500 \mathrm{bp}$ was observed when resolved using Agarose gel. The PCR amplicon was purified to remove contaminants. Forward and reverse DNA sequencing reaction of PCR amplicon was carried out with forward primer and reverse primers using BDT v3.1 Cycle sequencing kit on ABI 3730xl Genetic Analyzer. Consensus sequence of 16S rDNA gene was generated from forward and reverse sequence data using aligner software. The 16S rDNA gene sequence was used to carry out BLAST with the database of NCBI genbank database. Based on maximum identity score first ten sequences were selected and aligned using multiple alignment software program MEGA 7 followed by construction of the distance matrix and construction of the phylogenetic tree.

\subsubsection{Identification of Strain Specific Bacteria by Fatty Acid Methyl Ester (FAME) Analysis}

According to Kunitsky et al., 2005, the fatty acids were extracted from the growing bacterial culture by a procedure which consists of saponification in dilute sodium hydroxide/methanol solution (15g sodium hydroxide, $50 \mathrm{ml}$ methanol, and $50 \mathrm{ml}$ distilled water) followed by derivatization with dilute hydrochloric acid/methanol solution $(40.62 \mathrm{ml}$ certified $6.0 \mathrm{~N}$ hydrochloric acid and $34.37 \mathrm{ml}$ methyl alcohol $\mathrm{pH}$ value below 1.5 ) to give the respective methyl esters (FAMEs). The FAMEs were then extracted from the aqueous phase by the use of an organic solvent $(50 \mathrm{ml}$ hexane and $50 \mathrm{ml}$ methyl tert-butyl ether) and the resulting extract was analyzed by GC using Agilent HP-ULTRA 2 column which was of $25 \mathrm{~m}$ length, $0.200 \mathrm{~mm}$ diameter, $0.33 \mu \mathrm{m}$ film and its temperature limit is $60^{\circ} \mathrm{C}$ to $325^{\circ} \mathrm{C}$.In that gas chromatography, Hydrogen was used as mobile phase, Flame ionization detector as detector and its flow rate was $1.3 \mathrm{ml} / \mathrm{min}$. The software automated all analytical operations and used a sophisticated pattern recognition algorithm to match the unknown FAME profile to the stored library entries for identification by RTBA6 method. 


\subsubsection{Whole Genome and Plasmid Sequencing}

The DNA extraction from the bacteria $\mathrm{S} 6 \mathrm{C} 2$ was performed using standard kit based protocols (Oyedara et al., 2018). The DNA sample quality were checked using Nanodrop and quantitated using Qubit ds DNA BR assay (Thermo Scientific, USA). The genomic DNA was fragmented using Covaris to generate $300-400 \mathrm{bp}$ fragments. $100 \mathrm{ng}$ of fragmented DNA was used to generate sequencing library using NEBNext Ultra II DNA Library Prep Kit for Illumina (\#E7645S). In brief, the fragmented DNA was subjected to end repair followed by A-tailing and adapter ligation. Ampure bead based size selection was performed to obtain the library of desired size. The size selected DNA were enriched by PCR amplification using Illumina index adapter primers. The amplified product was purified using ampure beads to remove unused primers. The library was quantitated using Qubit DNA High Sensitivity quantitation assay and library quality was checked on 2100 using Agilent 7500 DNA Kit. The library was quantitated using Qubit DNA HS quantitation assay (Thermo Scientific) which specifically quantitates dsDNA assay. For sequencing, the libraries were diluted to $3 \mathrm{Nm}$ Using RSB and 5 uLs of the diluted library was mixed with an equal volume of freshly prepared $70.1 \mathrm{~N} \mathrm{NaOH}$ to allow the library to get denatured. The $\mathrm{pH}$ of the reaction was neutralized by adding $5 \mathrm{Ul}$ of freshly prepared $200 \mathrm{Mm}$ Tris- $\mathrm{HCl}$ and were taken on to Cbot for cluster generation on a HiSeqX high output flow cell. Cluster generation and sequencing was performed on the Illumina 2000 system. The following pipelines were used FastQC - To run and provide a QC report to check the quality of the sequences Galaxy (Unicycler + MOB) - To assemble the draft genome and to identify plasmid presence. RAST - To annotate the nuclear genome \&amp; Plasmid genome CONTIGuator - To finish the Genome assembly RNAmmer - To identify the $5 \mathrm{~s} / 8 \mathrm{~s}, 16 \mathrm{~s} / 18 \mathrm{~s}$, and $23 \mathrm{~s} / 28 \mathrm{~s}$ ribosomal RNA in full genome sequences. Genomic DNA. The circular plasmid map of the bacteria was created by CGVIEW Server. After the whole genome annotation, the existence of unique $\mathrm{ClpB}$ protein was identified and the bacterial whole genome sequences were submitted at NCBI under the Accession Number PRJNA555453.

\subsubsection{Isolation of Cellular Protein and SDS-PAGE Analysis}

The sample preparation was done according to Mathabe, 2014. The bacteria (S6C2) was grown in control (without arsenic) and $500 \mathrm{mg} . / 1$ of $\mathrm{As}(\mathrm{V})$ treated condition. After the incubation the bacterial cells were centrifuged $15,000 \mathrm{rpm}$ for 15 minutes (Remi C-24). The pellet was obtained and the cellular proteins were extracted with $100 \mu 1$ of $0.4 \%$ Triton-X. Then, the samples were centrifuged at 15,000 rpm for 15 minutes. The resulting pellet was resuspended in $4 \mathrm{X}$ loading buffer (consisting of $10 \mathrm{Mm}$ Tris- $\mathrm{HCl} \mathrm{pH} 6$, $277 \mathrm{mM}$ SDS and $40 \%$ Glycerol) and it was sonicated (Hielscher UP 200S, Hielscher Ultrasonics $\mathrm{GmbH}$, Germany) to recover the cellular proteins. After that, it was centrifuged and the supernatant was retained. SDS-PAGE analysis (Biorad, Richmond, CA) of the crude extract of the cellular proteins of the control and $500 \mathrm{mg} . / \mathrm{l} \mathrm{As}(\mathrm{V})$ treated samples were done.

\section{Results}

\subsection{Arsenic Concentration of Soil Sample}

Arsenic concentration of the collected soil sample from Shyamnagar was $0.51 \mathrm{mg} . / 1$ (Table-1).

Table 1. Characterization of Soil Sample

\begin{tabular}{|c|c|c|c|c|c|c|c|c|}
\hline $\begin{array}{c}\text { Sample } \\
\text { Name }\end{array}$ & $\begin{array}{c}\text { Texture of the } \\
\text { Soil Sample }\end{array}$ & Location & $\mathbf{p H}$ & $\begin{array}{c}\text { Temperature } \\
\left({ }^{\circ} \mathbf{C}\right)\end{array}$ & $\begin{array}{c}\text { EC value } \\
(\mathbf{d s} / \mathbf{m}) \text { of the } \\
\text { Soil Sample }\end{array}$ & $\begin{array}{c}\text { Specific } \\
\text { Gravity }\end{array}$ & $\begin{array}{c}\text { Arsenic } \\
\text { Content }\end{array}$ & Inference \\
\hline S-6 & Clay & $\begin{array}{c}\text { Paddy } \\
\text { rhizospheric soil } \\
\text { from Shyamnagar }\end{array}$ & 7.34 & 25 & 0.00247 & 0.997 & $0.51 \pm 0.001$ & $\begin{array}{c}\text { Neutral, non } \\
\text { saline in } \\
\text { nature }\end{array}$ \\
\hline
\end{tabular}




\subsection{Physical Characterization of Soil Sample}

Some physical characterization of the soil sample was done. The temperature of the soil sample was $25^{\circ} \mathrm{C}$. It was clay type because its $\mathrm{pH}$ value was 7.34. EC value and Specific Gravity value were $0.00247 \mathrm{dS} / \mathrm{m}$ and 0.997 respectively (Table 1).

\subsection{Isolation of Bacteria}

The bacterial colonies were isolated from $10^{-2}$ and $10^{-4}$ dilution plates. Numerous colonies were obtained in each plate. The four colonies were selected at random for further studies, i.e., morphological and biochemical characterization [Table 2 and Figure. 1.(a), (b)].

Table 2. Morphology of the Bacterial Strains

\begin{tabular}{|c|c|c|}
\hline Bacteria & Colony morphology & Gram's nature \\
\hline S6C1 Bacteria & Moderate in size, yellowish white, slimy, irregular, lobate margin, flat & Gram $(+)$, short rods \\
\hline S6C2 Bacteria & Small in size, whitish, slimy, circular, entire margin, flat & Gram $(+)$, short rods \\
\hline S6C3 Bacteria & Small in size, slightly yellowish, slimy, lobate margin, flat & Gram $(+)$, short rods \\
\hline S6C4 Bacteria & Large in size, whitish, slimy, irregular, undulate margin, slightly raised & Gram $(-)$, short rods \\
\hline
\end{tabular}

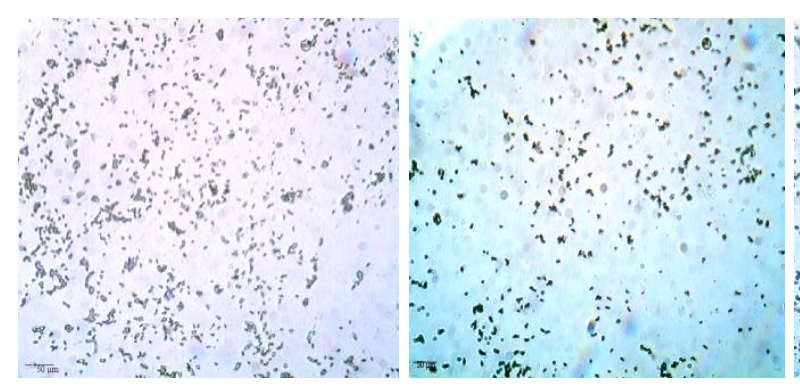

(a) (b)

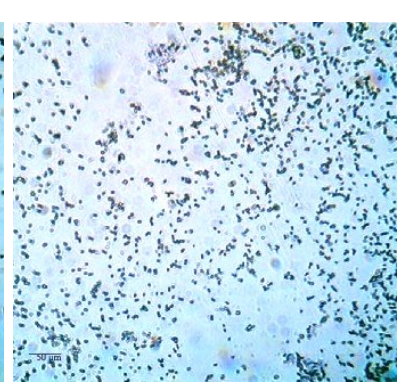

(c)

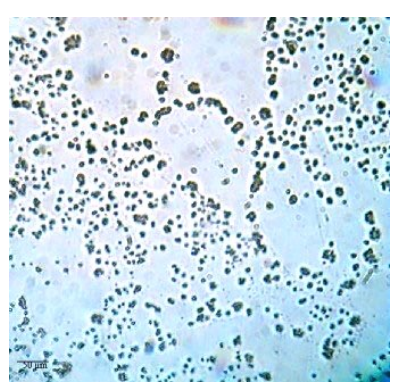

(d)

Figure 1. (a), (b), (c) and (d). Gram staining of S6C1, S6C2, S6C3 and S6C4 Bacteria under 40 X Magnification of Compound Light Microscope

\subsection{Biochemical Characterization of the Isolated Bacteria}

The results are tabulated in Table 3 and Table 4.

Table 3. Biochemical Characterization of the Bacteria

\begin{tabular}{|c|c|c|c|c|c|}
\hline Bacteria & Indole test & MR test & VP test & Citrate test & Chrome agar test \\
\hline S6C1 & - & - & - & + & Dark Blue Colony \\
\hline S6C2 & - & + & + & - & Brownish Orange Colony \\
\hline S6C3 & - & - & - & + & Dark Blue Colony \\
\hline S6C4 & - & - & - & + & Brownish Orange Colony \\
\hline
\end{tabular}

Table 4. Sugar Utilization Test

\begin{tabular}{|c|c|l|}
\hline Bacteria & \multicolumn{1}{|c|}{ Result } & Interpretation \\
\hline S6C1 & Red slant/Yellow Stab & $\begin{array}{l}\text { Glucose fermentation with acid production. Proteins catabolized aerobically (in the slant) with } \\
\text { alkaline products. }\end{array}$ \\
\hline S6C2 & Red slant/Yellow Stab & $\begin{array}{l}\text { Glucose fermentation with acid production. Proteins catabolized aerobically (in the slant) with } \\
\text { alkaline products. }\end{array}$ \\
\hline S6C3 & Red slant/Yellow Stab & $\begin{array}{l}\text { Glucose fermentation with acid production. Proteins catabolized aerobically (in the slant) with } \\
\text { alkaline products. }\end{array}$ \\
\hline S6C4 & Red slant/Yellow Stab & $\begin{array}{l}\text { Glucose fermentation with acid production. Proteins catabolized aerobically (in the slant) with } \\
\text { alkaline products. }\end{array}$ \\
\hline
\end{tabular}




\subsection{Arsenic Tolerance Study}

The isolated bacterial strains were inoculated in the nutrient broth (HiMedia) supplemented with increasing concentration of arsenic [As (V)] from $5 \mathrm{mg}$./l to $1000 \mathrm{mg}$./l because the bacterial strains have arsenate reduction ability. The $\mathrm{LD}_{50}$ value of $\mathrm{S} 6 \mathrm{C} 1, \mathrm{~S} 6 \mathrm{C} 2$, S6C3 and $\mathrm{S} 6 \mathrm{C} 4$ were $30 \mathrm{mg} . / 1,500 \mathrm{mg} . / 1,300 \mathrm{mg} . / 1$ and $50 \mathrm{mg} . / 1$ respectively [Figure. 2.(a),(b),(c),(d),(e),(f),(g) and (h)].

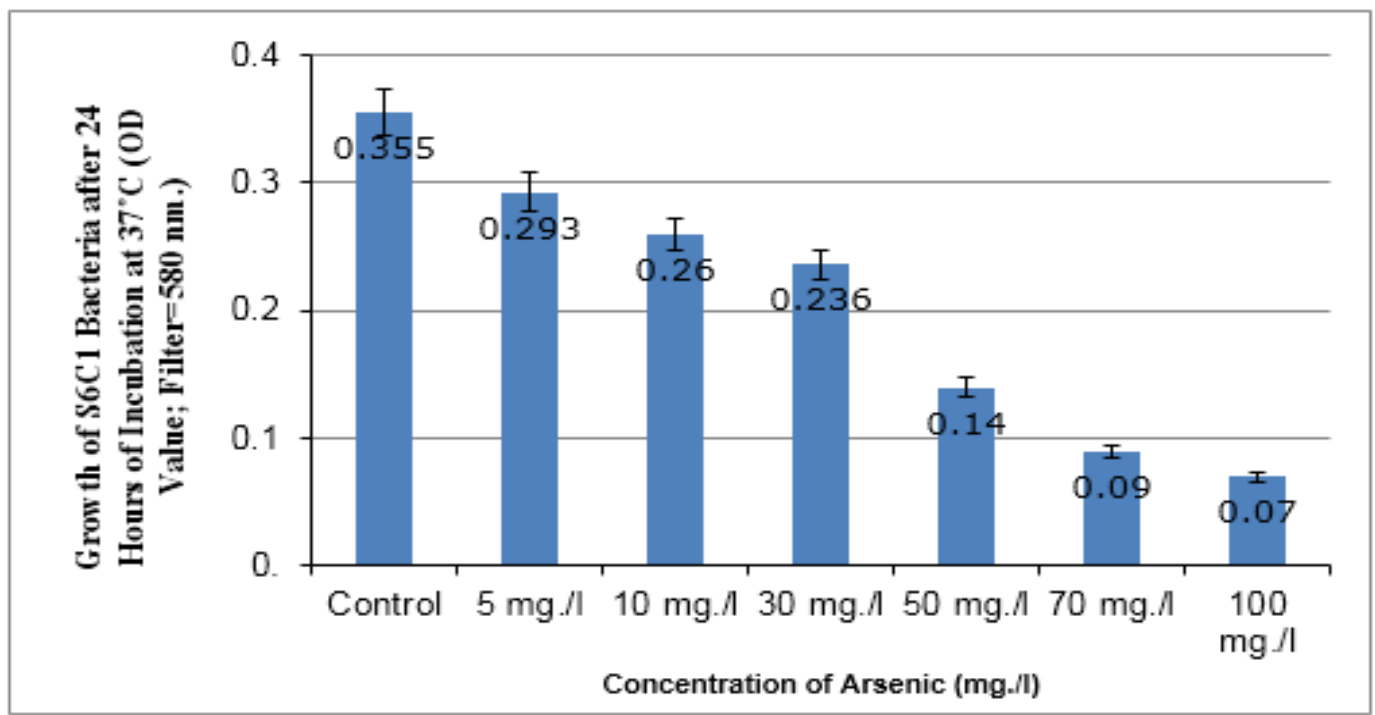

(a)

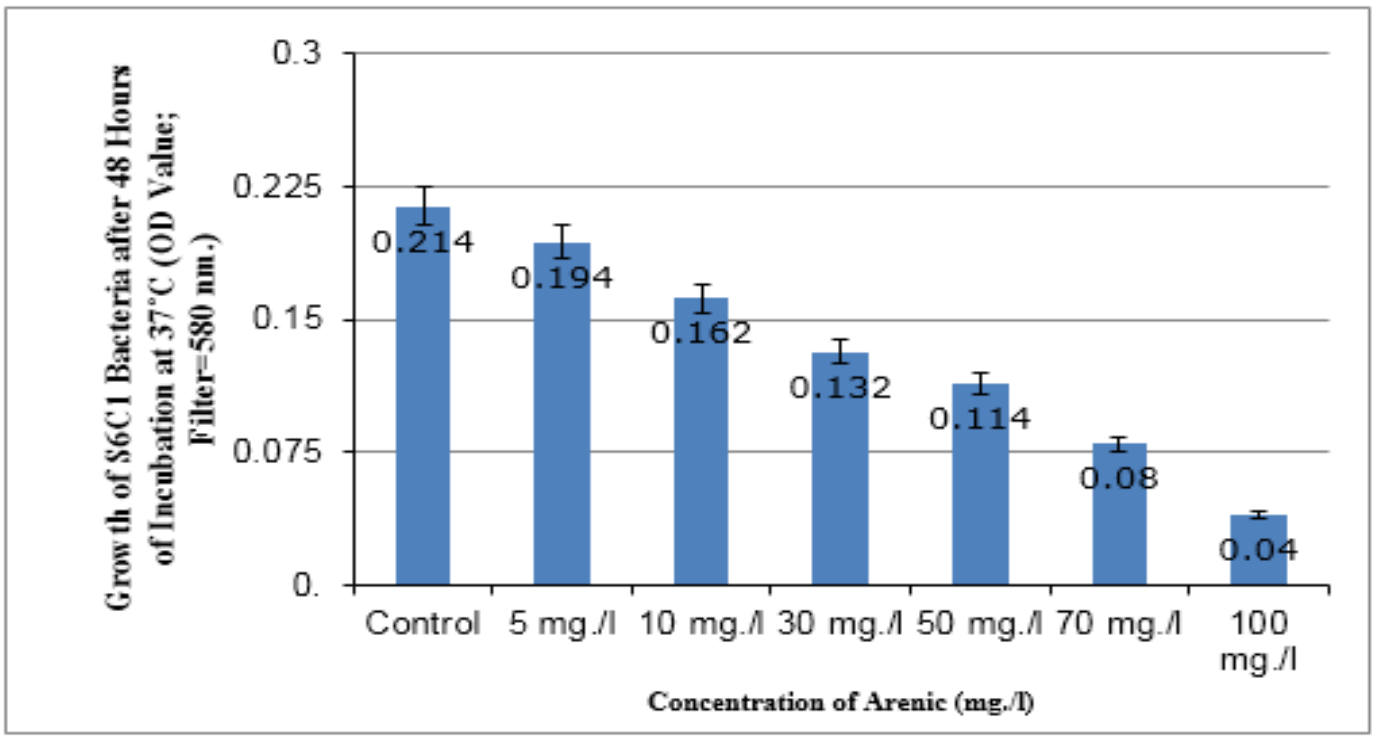

(b) 


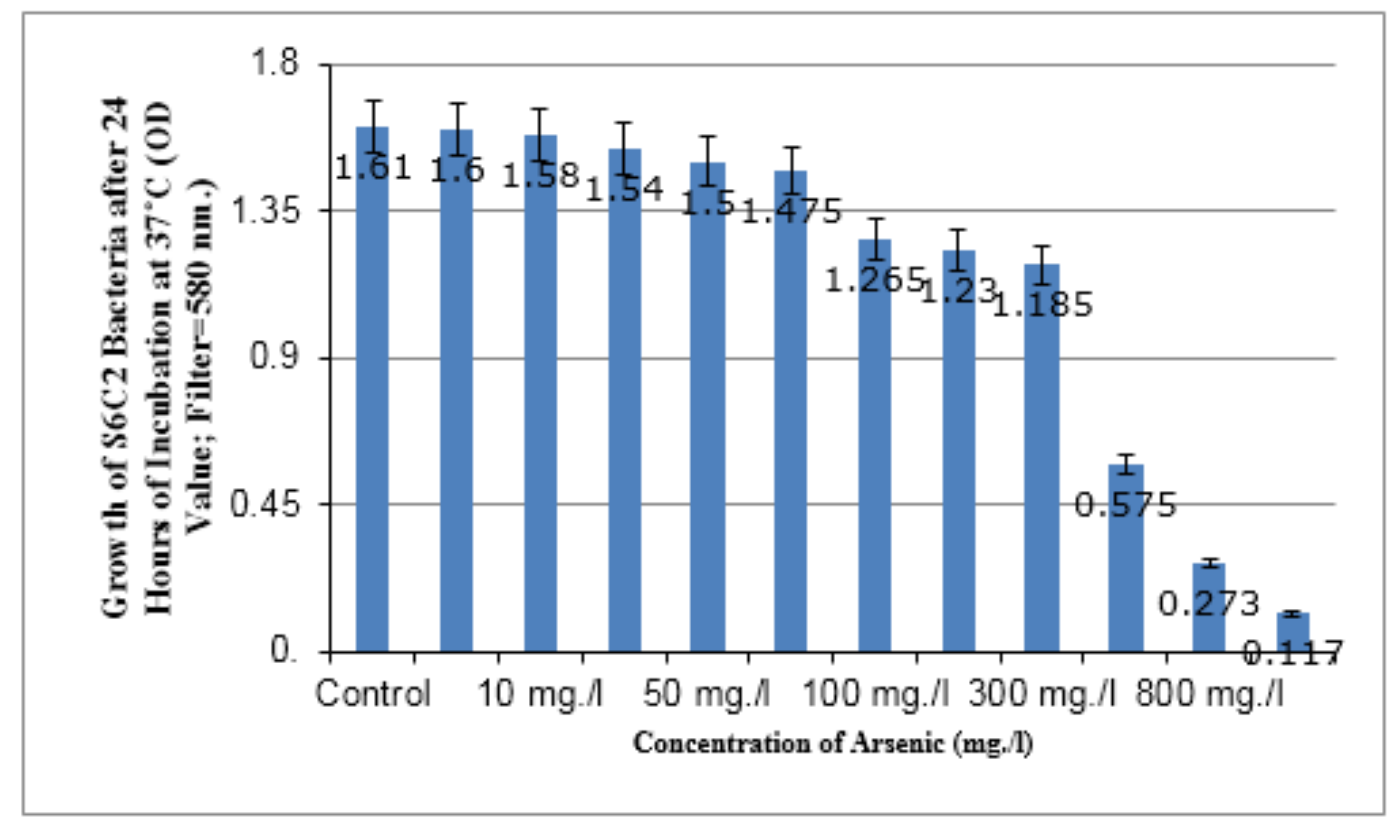

(c)

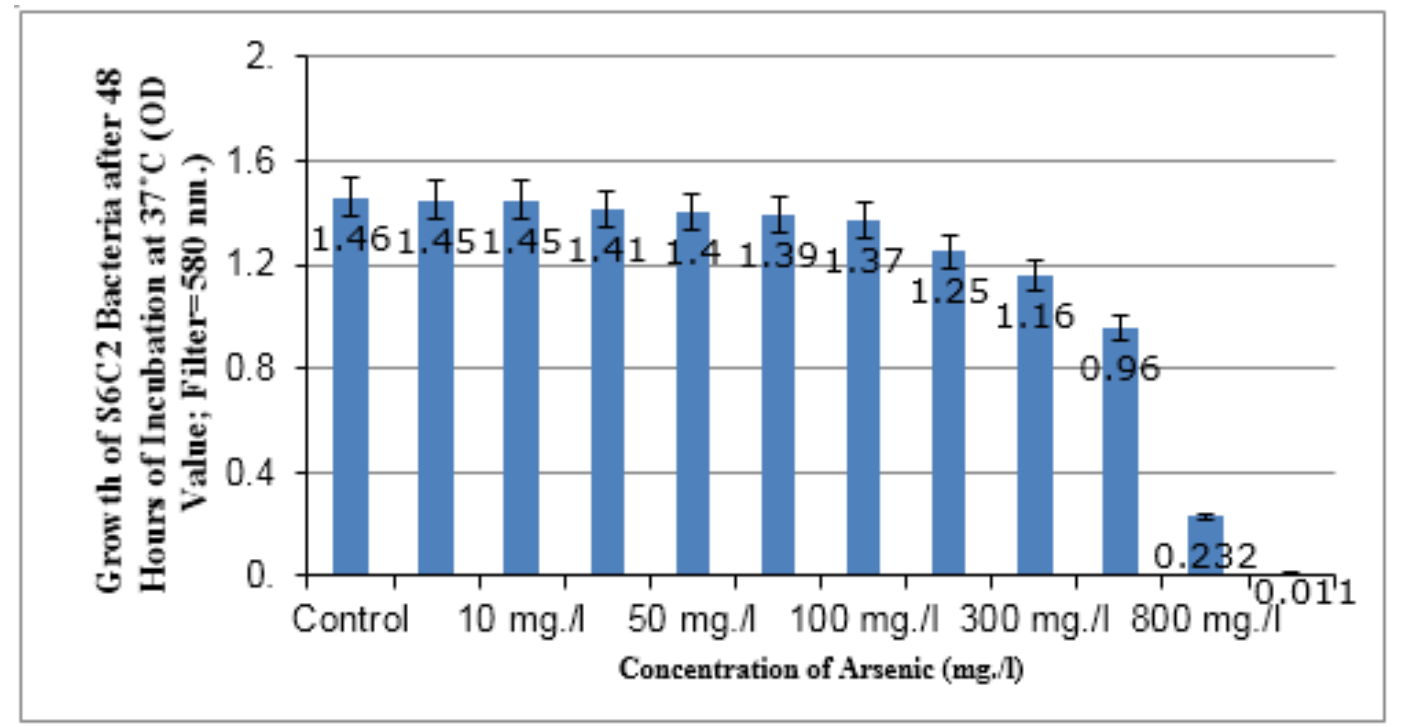

(d) 


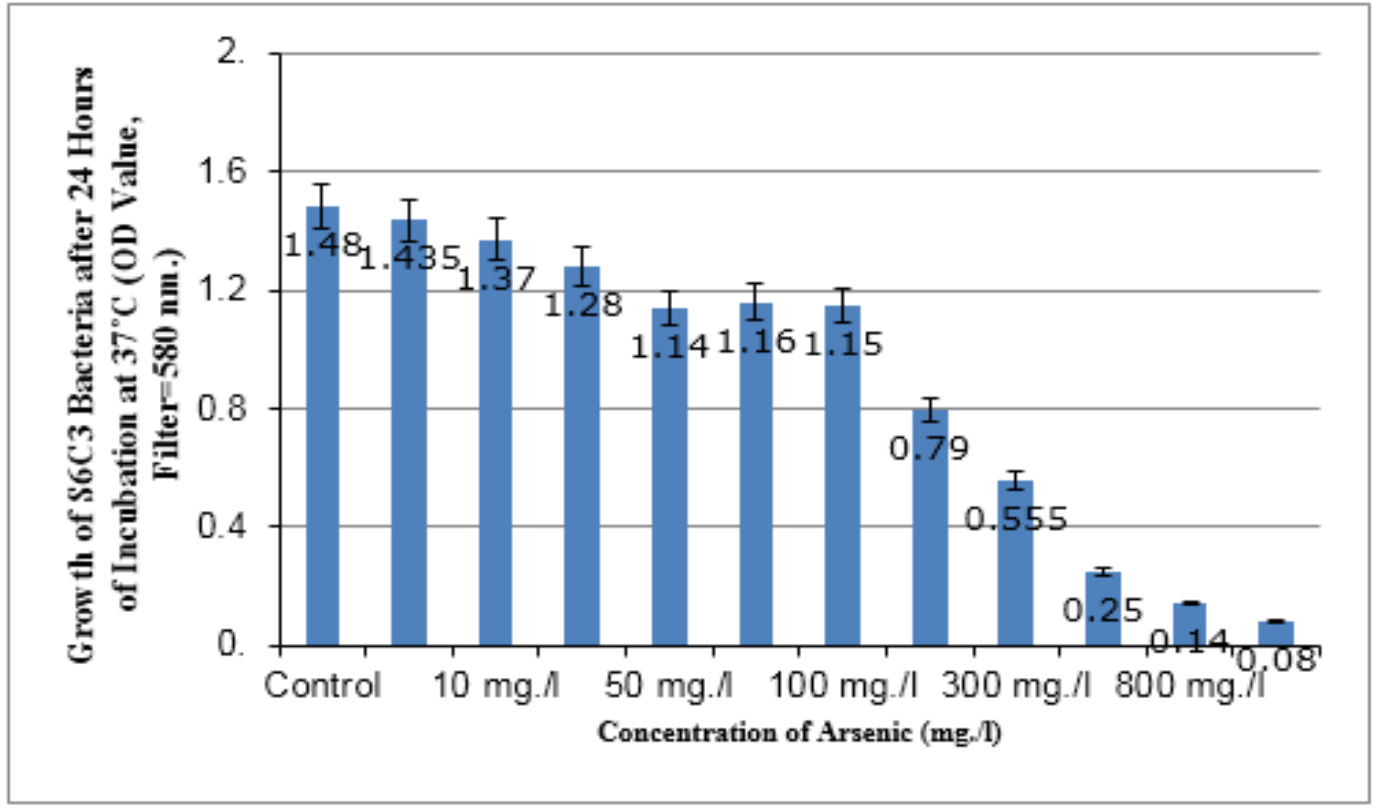

(e)

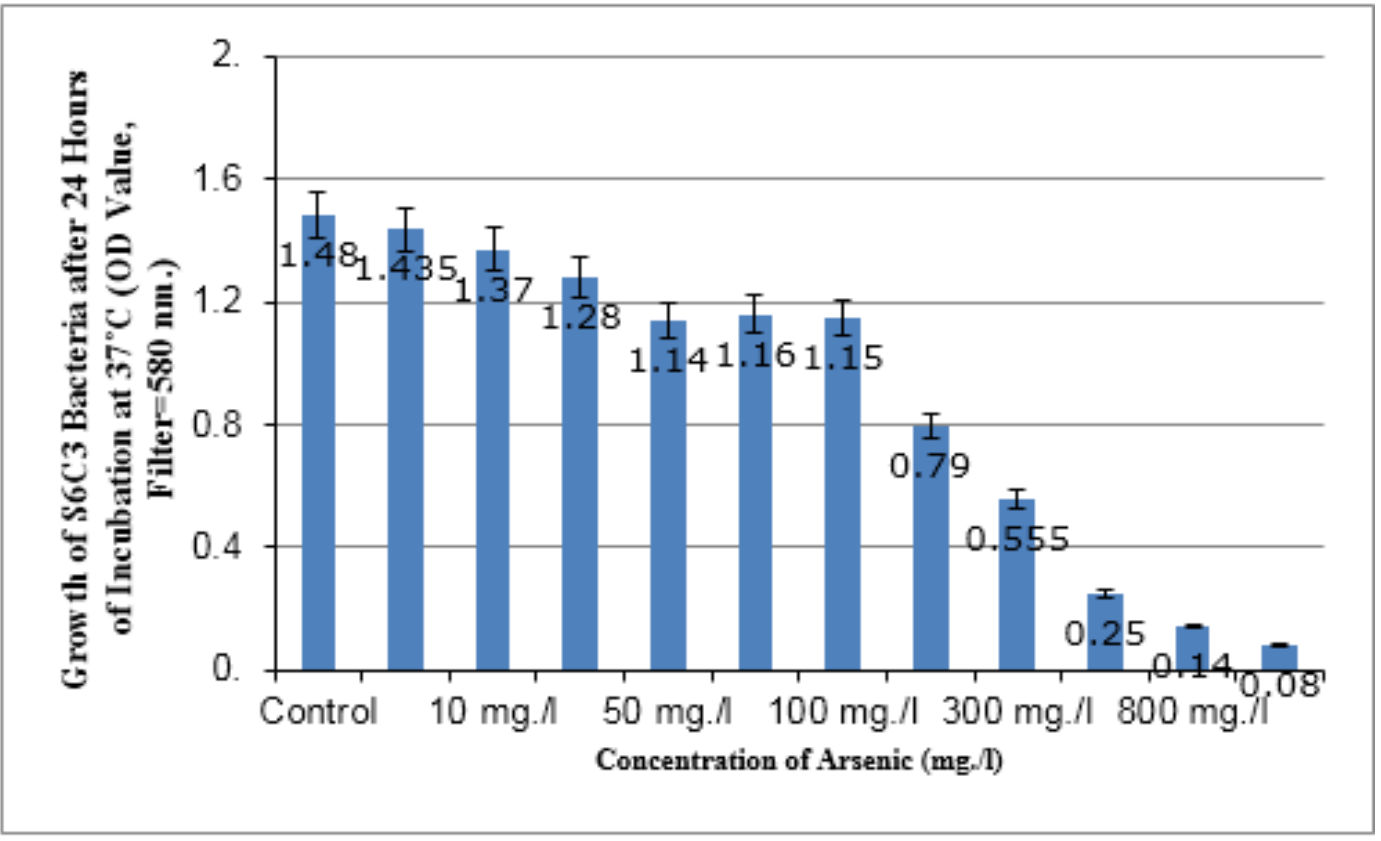

(f) 


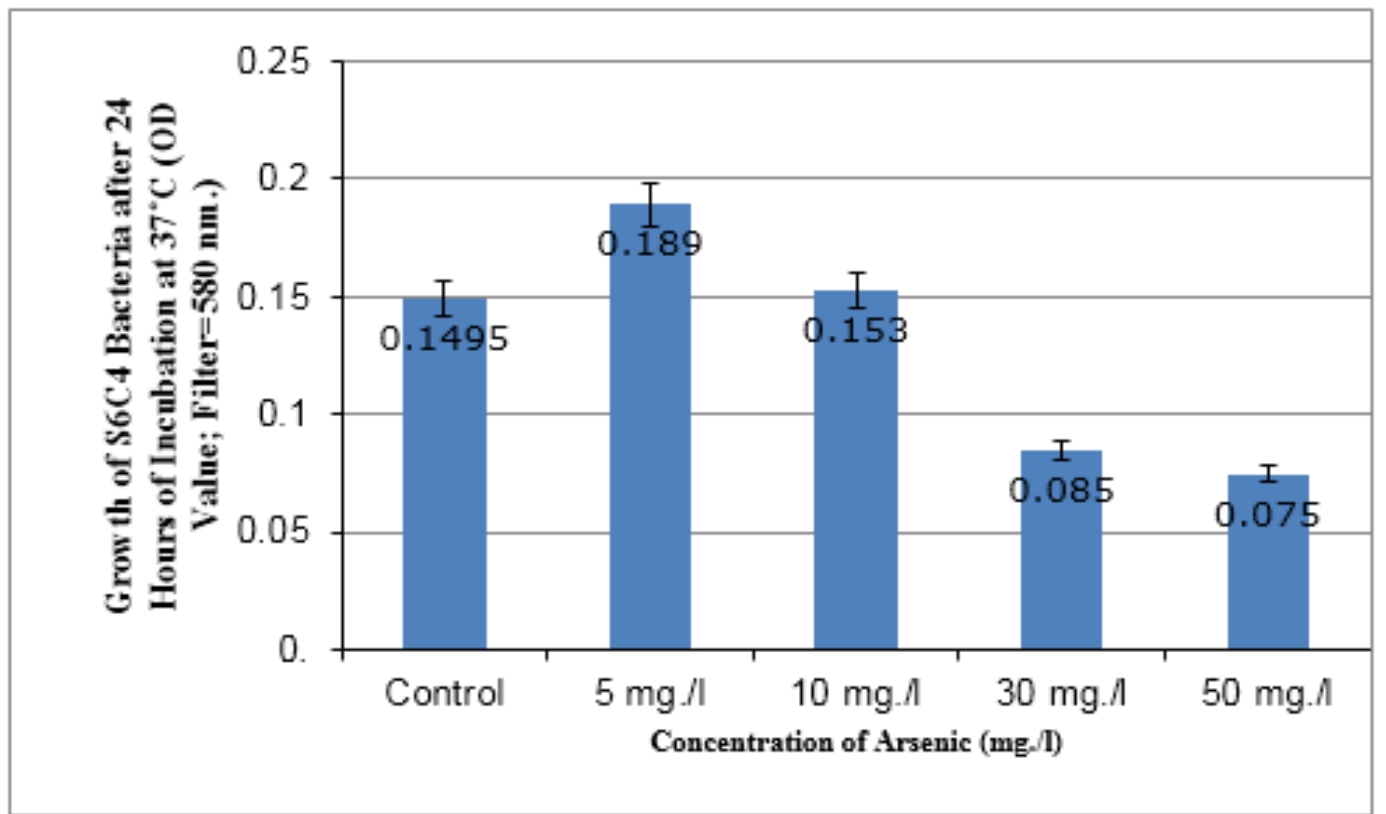

(g)

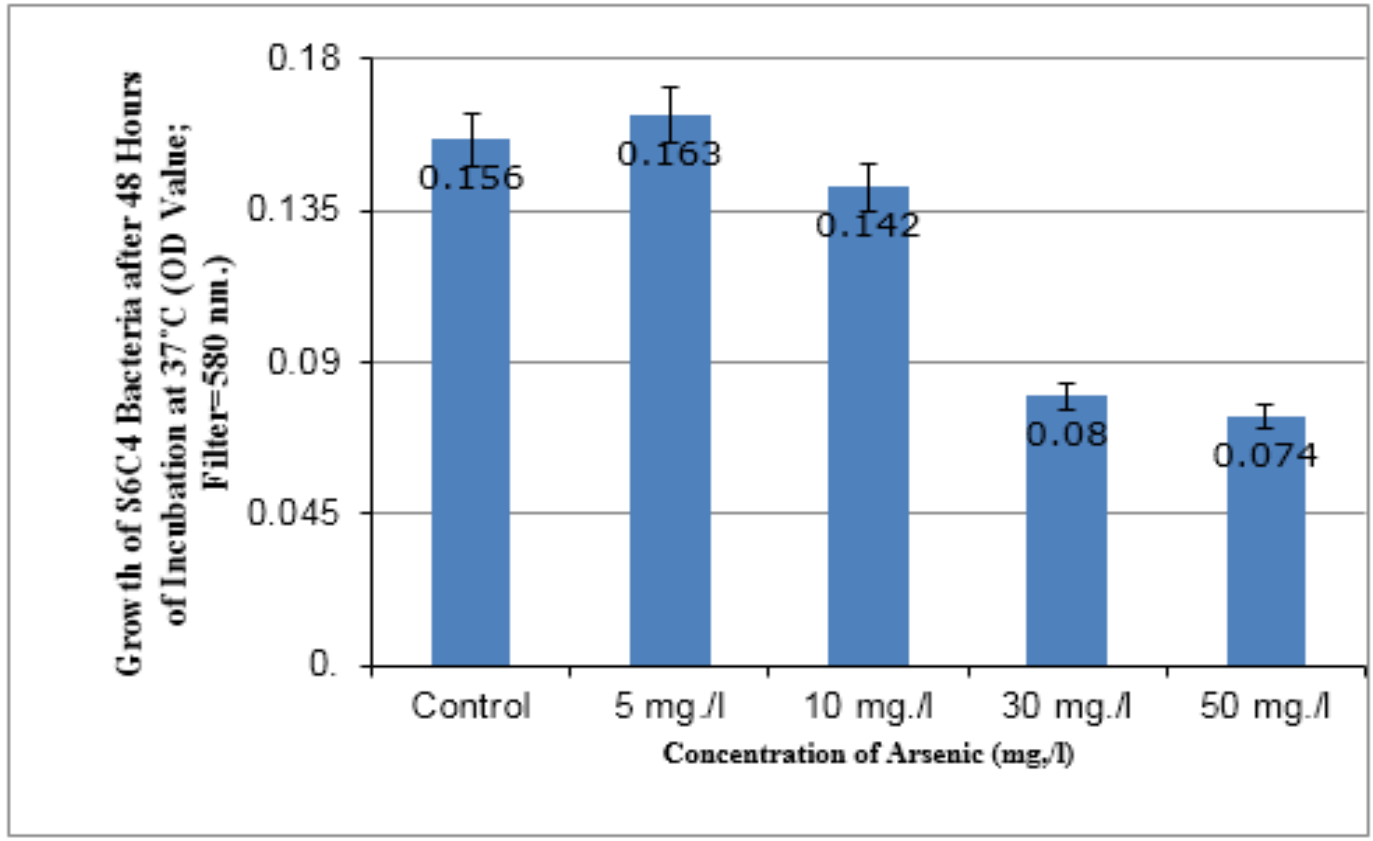

(h)

Figure 2. (a), (b), (c), (d), (e), (f), (g) and (h). Arsenic Tolerance Study of S6C1, S6C2, S6C 3 and $\mathrm{S} 6 \mathrm{C} 4$ Bacteria at $37^{\circ} \mathrm{C}$ in BOD Incubator Shaker after 24 Hours and 48 Hours of Incubation respectively

\subsection{Uptake of Arsenic by the Bacteria}

The percentage uptake of arsenic [As (V)] by S6C1, S6C2, S6C3 and S6C4 bacteria were $11.46 \%, 52.20 \%, 11.56 \%$ and $10.84 \%$ respectively (Table 5 ).

Table 5. Arsenic Uptake by Bacteria

\begin{tabular}{|c|c|c|c|c|}
\hline Bacteria & $\begin{array}{c}\text { Concentration of Arsenic } \\
\text { (mg./l) }\end{array}$ & $\begin{array}{c}\text { Residual Arsenic in the } \\
\text { Medium (mg./l) }\end{array}$ & $\begin{array}{c}\text { Uptake of Arsenic by the } \\
\text { Bacteria (mg./l) }\end{array}$ & $\begin{array}{c}\text { \% Uptake of Arsenic by } \\
\text { the Bacteria }\end{array}$ \\
\hline S6C1 & 30 & $26.56 \pm 0.1$ & 3.44 & $11.46 \%$ \\
\hline S6C2 & 500 & $239 \pm 0.1$ & 261 & $52.2 \%$ \\
\hline S6C3 & 300 & $265.3 \pm 0.1$ & 34.7 & $11.56 \%$ \\
\hline S6C4 & 50 & $44.58 \pm 0.1$ & 5.42 & $10.84 \%$ \\
\hline
\end{tabular}




\subsection{SEM-EDX}

The scanning electron micrographs of $\mathrm{S} 6 \mathrm{C} 2$ bacterial cells without arsenic (control) and with exposure to arsenic [500 mg./l of As(V)] were studied in mid-log phase. Cellular morphology of S6C2 bacteria in the presence of As(V) and was changed in mid-log phase and the cells became elongated [Fig. 3.(a) and (b)]. The energy dispersive X-ray spectroscopy (EDX) analysis showed a distinct EDX signal corresponding to arsenic peak was observed in presence of As(V) loaded cells [Fig. 3.(d)] however, no such peak was observed in control [Fig. 3.(c)].

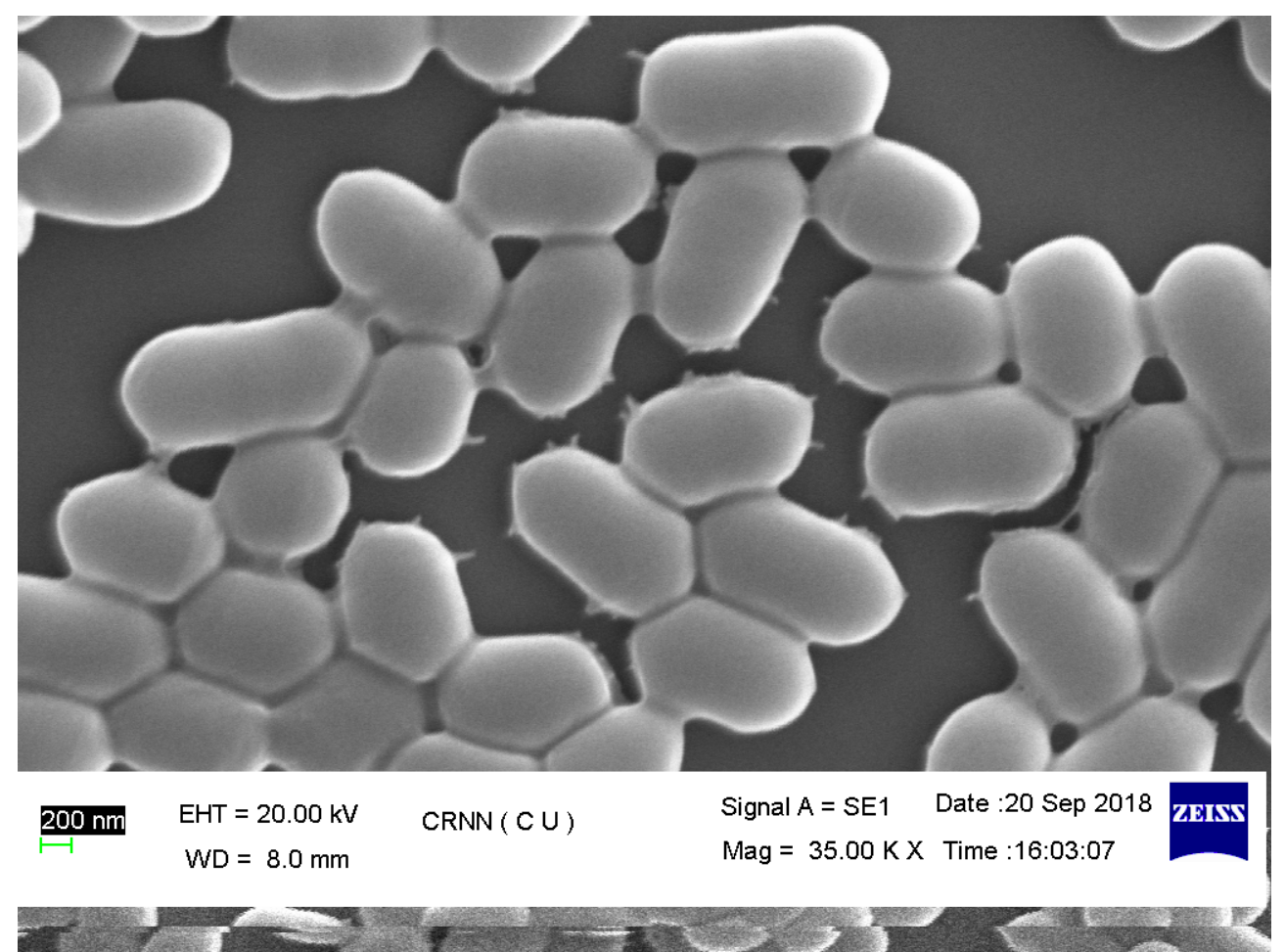

(a)

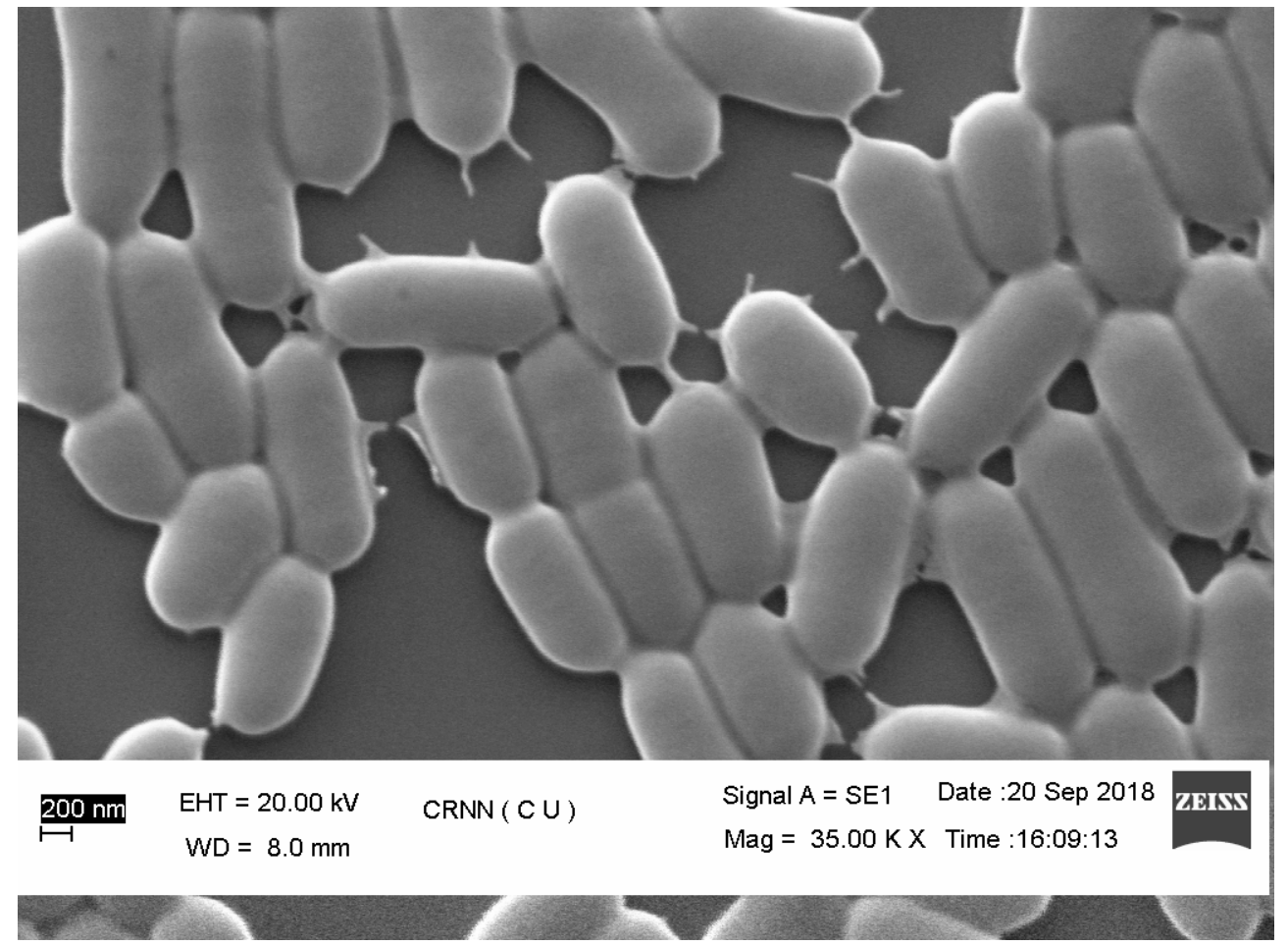

(b) 


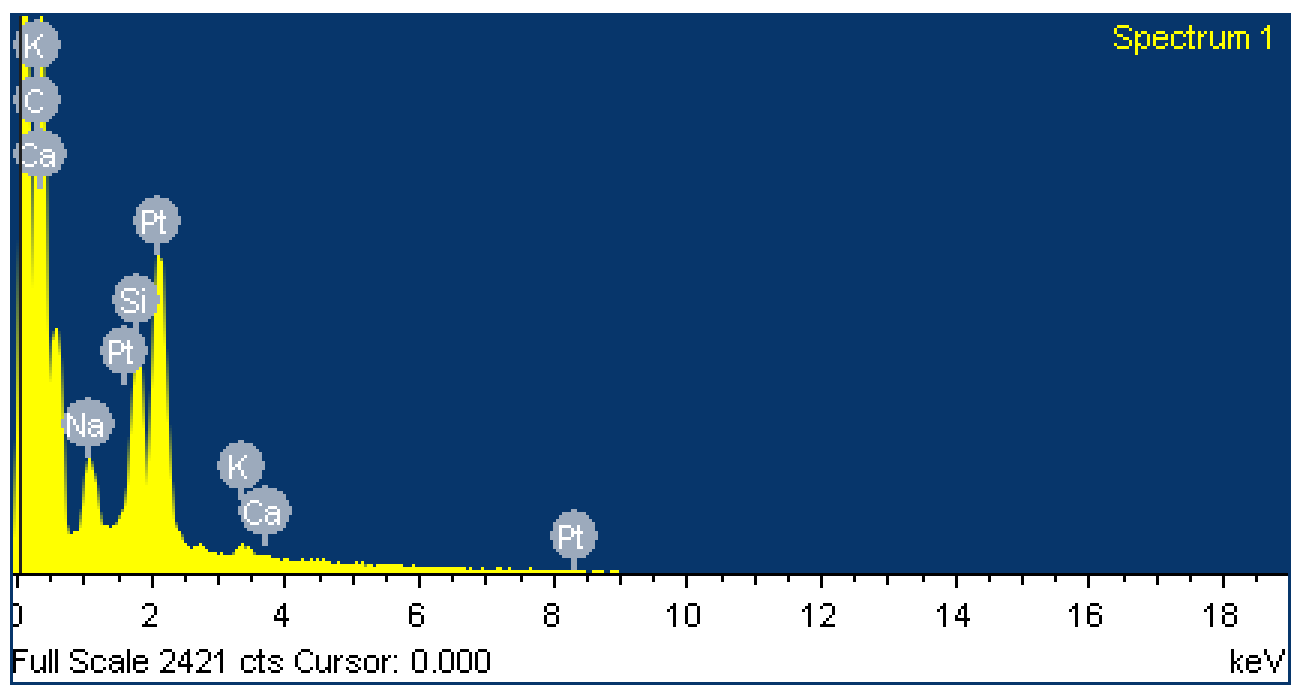

(c)

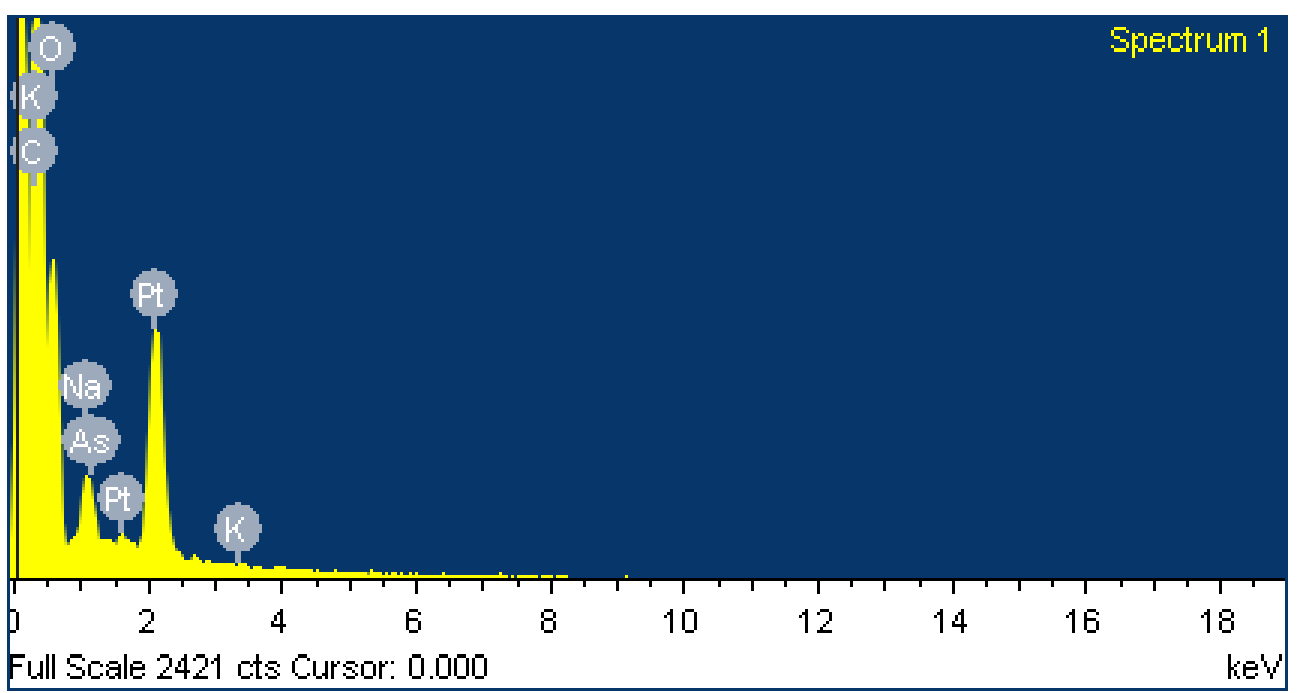

(d)

Figure 3. (a). Scanning Electron Micrographs of $\mathrm{S} 6 \mathrm{C} 2$ Bacteria in Control, (b). Scanning Electron Micrographs of S6C2 Bacteria in Arsenic Treatment $[\mathrm{As}(\mathrm{V})]$, (c). Energy Dispersive X Ray Spectrum of S6C2 Bacteria in control and (d). Energy Dispersive X Ray Spectrum of S6C2 Bacteria in Arsenic Treatment $[\mathrm{As}(\mathrm{V})]$ condition

\subsection{Bacterial Viability Test by INT Assay}

Based on the higher arsenic As (V) tolerant ability, $\mathrm{S} 6 \mathrm{C} 2$ and $\mathrm{S} 6 \mathrm{C} 3$ bacterial cells were tested for viability assay with the help of INT. The decreasing amount of cell viability of S6C2 and S6C3 bacteria were $41.34 \%$ and $43.35 \%$ respectively [Supplementary Table 1, Figure. 1.(a),(b) and 2.(a) and (b)].

\subsubsection{Bacterial Identification by $16 \mathrm{~S}$ rDNA Sequence Analysis}

S6C2 bacteria showed high similarity with Exiguobacterium indicum based on nucleotide homology and phylogenetic analysis (Figure. 4 and Table 6). 


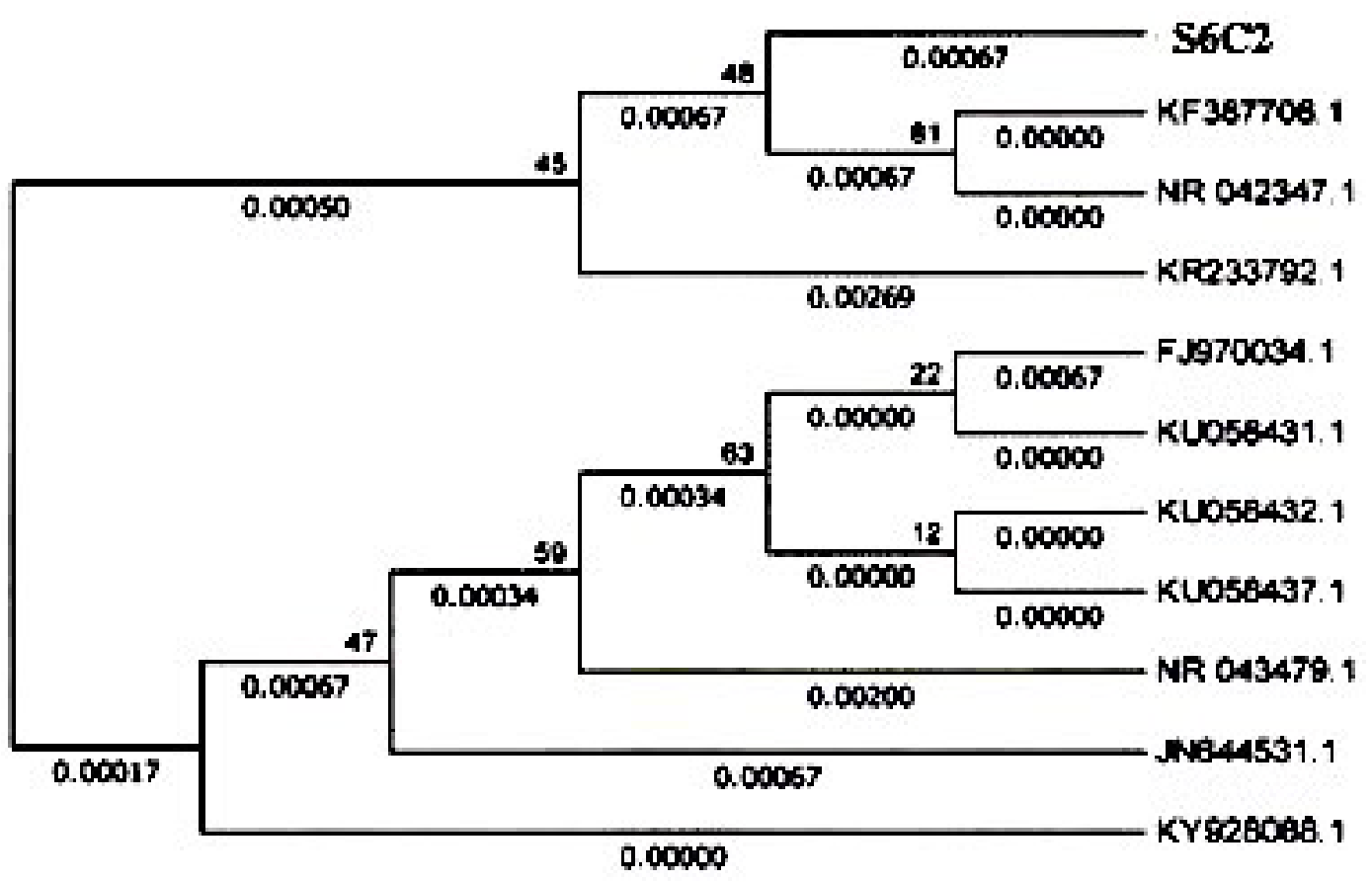

Figure 4. Molecular Phylogenetic analysis by Maximum Likelihood method on the Kimura 2-parameter model. Strains in the tree are: Exiguobacterium indicum strainBR18_1A (JN644531.1), Exiguobacterium indicum strainK1 (KY928088.1), Exiguobacterium indicum strain BPc2 (KF387706.1), Exiguobacterium acetylicum strainQD-3 (FJ970034.1), Exiguobacterium indicum strain HHS 31 (NR_042347.1), Exiguobacterium acetylicum strain DSM20416 (NR_043479.1), Exiguobacterium indicum strainS2KU058432.1, Exiguobacterium indicum strainV5 (KU058437.1), Exiguobacterium acetylicum strainS1 (KU058431.1), Exiguobacterium indicum strain IHBB10090 (KR233792.1).

Table 6. Estimates of Evolutionary Divergence between Sequences

\begin{tabular}{|c|c|c|c|c|c|c|c|c|c|c|c|}
\hline S6C2 & & 0.001 & 0.001 & 0.001 & 0.001 & 0.001 & 0.002 & 0.001 & 0.001 & 0.001 & 0.002 \\
\hline JN644531.1 & 0.002 & & 0.001 & 0.001 & 0.001 & 0.001 & 0.001 & 0.001 & 0.001 & 0.001 & 0.002 \\
\hline KY928088.1 & 0.002 & 0.001 & & 0.001 & 0.001 & 0.001 & 0.001 & 0.001 & 0.001 & 0.001 & 0.001 \\
\hline KF387706.1 & 0.001 & 0.002 & 0.002 & & 0.002 & 0.000 & 0.002 & 0.002 & 0.002 & 0.002 & 0.002 \\
\hline FJ970034.1 & 0.003 & 0.002 & 0.002 & 0.004 & & 0.002 & 0.001 & 0.001 & 0.001 & 0.001 & 0.002 \\
\hline NR_042347.1 & 0.001 & 0.002 & 0.002 & 0.000 & 0.004 & & 0.002 & 0.002 & 0.002 & 0.002 & 0.002 \\
\hline NR_043479.1 & 0.004 & 0.003 & 0.003 & 0.005 & 0.003 & 0.005 & & 0.001 & 0.001 & 0.001 & 0.002 \\
\hline KU058432.1 & 0.002 & 0.001 & 0.001 & 0.003 & 0.001 & 0.003 & 0.002 & & 0.000 & 0.000 & 0.002 \\
\hline KU058437.1 & 0.002 & 0.001 & 0.001 & 0.003 & 0.001 & 0.003 & 0.002 & 0.000 & & 0.000 & 0.002 \\
\hline KU058431.1 & 0.002 & 0.001 & 0.001 & 0.003 & 0.001 & 0.003 & 0.002 & 0.000 & 0.000 & & 0.002 \\
\hline KR233792.1 & 0.004 & 0.005 & 0.003 & 0.004 & 0.005 & 0.004 & 0.006 & 0.005 & 0.005 & 0.005 & \\
\hline
\end{tabular}

The number of base substitutions per site from between sequences are shown. Standard error estimate(s) are shown above the diagonal. Analyses were conducted using the Kimura 2- parameter model. The analysis involved 11 nucleotide sequences. Codon positions included were $1 \mathrm{st}+2 \mathrm{nd}+3 \mathrm{rd}+$ Noncoding. All positions containing gaps and missing data were eliminated. There were a total of 1494 positions in the final dataset. Evolutionary analyses were conducted in MEGA7.

\subsubsection{Fatty Acid Methyl Ester (FAME) Analysis}

A large number of derivetized (methyl ester) fatty acids which can be considered as marker for the specimen. The major fatty acid $(>5 \%)$ S6C2 Bacteria were Iso-C15:0
(20.30\%), Iso-C17:0 (15.07\%), C16:0 (9.62\%), Iso-C13:0 (7.36\%), Anteiso C13:0 (11.37\%), Anteiso C15:0 (7.98\%) and Anteiso C17:0 (6.22\%). However unique existence of $\mathrm{C}: 10: 03 \mathrm{OH}(0.53 \%), \mathrm{C} 12: 1$ at $11-12(0.16 \%), \mathrm{C} 11: 03 \mathrm{OH}$ (0.38\%), Anteiso C14:0 (Terminally branched Myristic Acid ) (0.74\%), C15:1w5C (0.25\%), C16:0 N Alcohol (0.45\%), Anteiso 16:0 (Anteiso Palmitic Acid) (0.36\%), Iso- C16:0 3OH (3 Hydroxy Hexane decanoic acid/ Palmitic acid ) (0.33\%), Iso- C18:1 H (Oleic Acid) (0.25\%), C18:3w6C $(6,9,12)$ (Alpha Linolenic acid ) $(0.53 \%), \mathrm{C} 18: 1$ $2 \mathrm{OH}$ (2 Hydroxy Oleic acid $(0.52 \%)$ fatty acids were observed in the fatty acid profile of the unique bacterial strain. So, the unique bacteria was named as Exiguobacterium indicum Strain DSAM62 (Figure.5 and Supplementary Table 2). 
FID1 A, (E17C23.595\A0062119.D)

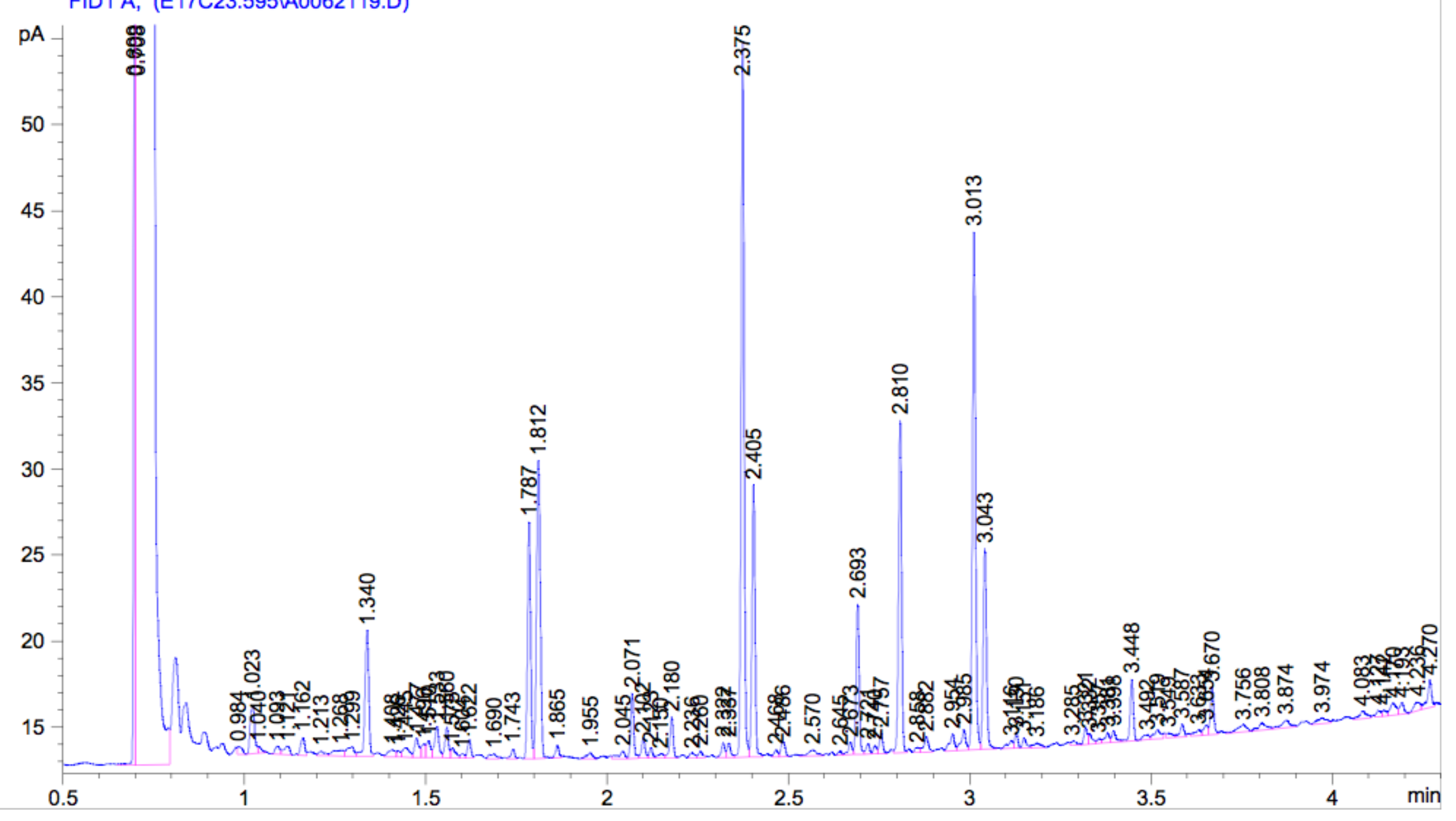

Figure 5. Chromatograph of Fatty Acids of Exiguobacterium indicum Strain DSAM 62 


\subsubsection{Genome Sequencing}

Whole genome and plasmid sequencing showed that the total assembled genome size of Exiguobacterium indicum Strain DSAM 62 was $3.1 \mathrm{Mb}$ with 19 scaffolds. Out of these, 18 scaffolds were present in $2.9 \mathrm{Mb}$ genomic DNA and 1 scaffold was present in $263 \mathrm{~Kb}$ of plasmid DNA. The bacteria had the several genes which could be related to arsenic resistance behavior (Supplementary Table 3). The whole genome sequence is a complete structural and functional annotated sequence which will be an important data to correlate the experimental and computational studies.

\subsubsection{Cellular Protein Isolation and SDS-PAGE Analysis}

Two distinct bands were found in the $\mathrm{As}(\mathrm{V})$ treated sample at about $96 \mathrm{kDa}$ and $76 \mathrm{kDa}$. Among these two bands only $96 \mathrm{kDa}$ molecular weight band was found in case of $500 \mathrm{mg} . / 1$ of $\mathrm{As}(\mathrm{V})$ treated sample, which may correspond to be $\mathrm{ClpB}$ protein as the gene for that protein is present in the genome assembly and previous reports (Tsuchiya et al., 2019) do predict the role of the protein in response to arsenic stress (Figure. 6). This needs to be tested further to confirm the role of the protein under conditions of arsenic uptake in this bacterium.

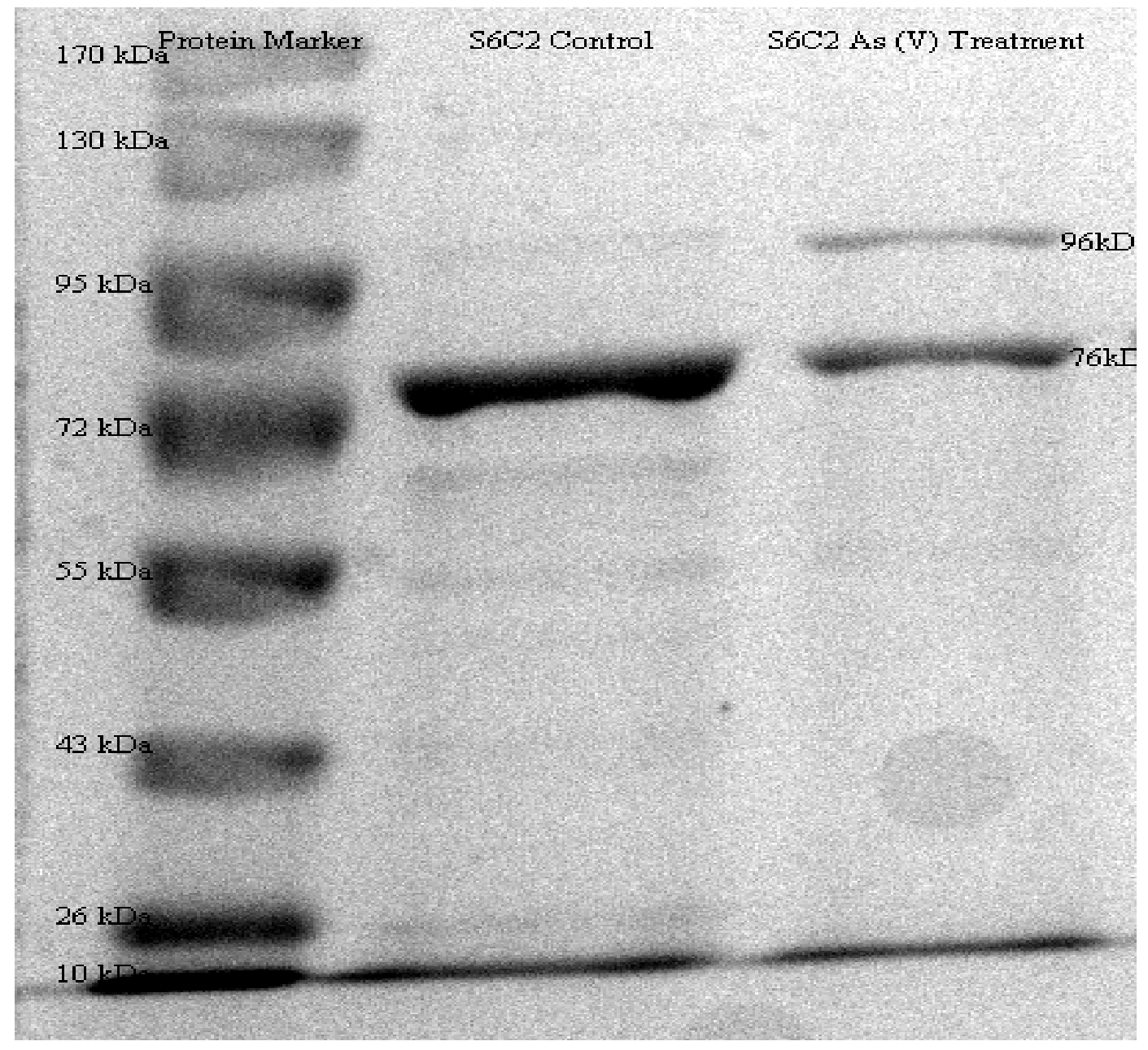

Figure 6. SDS-PAGE Analysis of the Membrane Protein of S6C2 Bacteria, Lane 1, Prestained Protein Ladder, Lane 2 Control and Lane 3 As(V) (500 mg./l) Treated Exiguobacterium indicum Strain DSAM 62 


\section{Discussion}

According to Castro-Severyn et al., 2017 and Albarracin et al., 2016, psychrophilic bacteria Exiguobacterium was normally found in the extreme environmental condition of Chilean Altiplano, Atacama desert, Antarctic ice (Carneiro et al., 2012), Himalayan glaciers (Chaturvedi and Shivaji, 2006), soda lakes (Borsodi et al., 2005), hyperthermophilic hot springs (Vishnivetskaya et al., 2009), and deep-sea hydrothermal vents (Vishnivetskaya et al., 2009 and Crapart, 2007). They had been reported to persist in effluent of paper mills and in rhizospheres of Lemna minor (Kashamaet al., 2009 and Tang et al., 2013). The genetic differentiation of Exiguobacterium were found due to the ecology of diverse habitats (e.g., CuatroCiénagas: Rebollar et al., 2012). According to Castro-Severynet al., 2017 Exiguobacterium sp. Strain SH31 was arsenic resistant and it was able to survive in the media supplemented with 100 $\mathrm{mM}$ of Arsenic; i.e. As(V). Pandey and Bhatt, 2015 described in their study that Exiguobacterium sp. (As-09) was tolerant to arsenic upto $700 \mathrm{mM}$, which was isolated from an arsenic contaminated soil from Rajnandgaon district, Chattisgarh, India. Sacheti et al, 2013, isolated Exiguobacterium sp. PS from the arsenic contaminated site in India. According to the study of Belifore, et al., 2013, that arsenic resistant Exiguobacterium sp. S17 was isolated from a high-altitude Andean lake stromatolite.

In the present study, the four bacteria were isolated from the soil sample of Shyamnagar, 24 Parganas (North). The $\mathrm{LD}_{50}$ value of the isolated $\mathrm{S} 6 \mathrm{C} 1, \mathrm{~S} 6 \mathrm{C} 2, \mathrm{~S} 6 \mathrm{C} 3$ and $\mathrm{S} 6 \mathrm{C} 4$ bacteria were $30 \mathrm{mg} . / 1,500 \mathrm{mg} . / 1,300 \mathrm{mg} . / 1 \mathrm{and} 50 \mathrm{mg} . / 1 \mathrm{lof}$ arsenic As (V) respectively. The uptake ability of $\mathrm{S} 6 \mathrm{C} 1$, $\mathrm{S} 6 \mathrm{C} 2, \mathrm{~S} 6 \mathrm{C} 3$ and $\mathrm{S} 6 \mathrm{C} 4$ bacteria were $11.46 \%, 52.2 \%$, $11.56 \%$ and $10.84 \%$ respectively. Depending on their higher arsenic tolerance ability the cell viability test through INT assay were done in case of two bacteria viz. $\mathrm{S} 6 \mathrm{C} 2$ and $\mathrm{S} 6 \mathrm{C} 3$ bacteria among these four bacteria. In this assay, the decreasing cell viability value of $\mathrm{S} 6 \mathrm{C} 2$ and $\mathrm{S} 6 \mathrm{C} 3$ bacteria were found to be $41.34 \%$ and $43.35 \%$ in their respective $\mathrm{LD}_{50}$ value i.e $500 \mathrm{mg} . / \mathrm{l}$ and $300 \mathrm{mg} . / 1$ of arsenic $\mathrm{As}(\mathrm{V})$ respectively and the amount was the near about $50 \%$. From these results, it was concluded the fact that the bacteria $\mathrm{S} 6 \mathrm{C} 2$ isolated shows an extreme tolerance towards this heavy metal and this indicates that further molecular studies must be performed in order to understand the molecular basis of this tolerance in order to shed light on the fact that how they can be used in contaminated fields as a potential bioremediator of this heavy metal. Metal tolerant bacteria usually have the ability to internalize and metabolize heavy metals to more non toxic gaseous forms (Chen et al .2014) such that a part of the arsenic in the biomass can be encompassed within the atmosphere essentially reducing the gross quantitated level of arsenic from the soil.

On the basis of the higher arsenic tolerance and uptake efficacy, $\mathrm{S} 6 \mathrm{C} 2$ bacteria was identified as Exiguobacterium indicum by showing high similarity based on nucleotide homology and phylogenetic analysis. After fatty acid methyl ester (FAME) analysis, the major fatty acid (>5\%) $\mathrm{S} 6 \mathrm{C} 2$ Bacteria were terminally branched Iso-C15:0 (20.30\%), Iso-C17:0 (15.07\%), straight chain saturated C16:0 (9.62\%), terminally branched Iso-C13:0 (7.36\%), Anteiso C13:0 (11.37\%), terminally branched Anteiso C15:0 (7.98\%) and terminally branched Anteiso C17:0 $(6.22 \%)$. However unique presence monosaturated of $\mathrm{C}: 10: 03 \mathrm{OH}(0.53 \%), \mathrm{C} 12: 1$ at $11-12(0.16 \%), \mathrm{C} 11: 03 \mathrm{OH}$ $(0.38 \%)$, Anteiso C14:0 (0.74\%), monosaturated C15:1w5C, C16:0 N Alcohol, Anteiso 16:0 (0.36\%), IsoC16:0 3OH (0.33\%), Iso- C18:1 H (0.25\%), C18:3w6C $(6,9,12)(0.53 \%), \mathrm{C} 18: 12 \mathrm{OH}(0.52 \%)$ fatty acids were found in the fatty acid profile of the unique bacterial strain .Upon identifying this unique strain, our goal was to identify broadly the genes which were present in the species as a whole in order to get hold of an idea of the gross genomic blueprint which would enable to draw better conclusions on this tolerance. So, the further molecular level of studies was initiated. Whole genome and plasmid sequencing revealed that the bacteria indeed harbors several genes which could be linked to this unique resistance behavior. The whole genome sequence is a complete structural and functional annotated sequence which will be an excellent tool to substantiate experimental and computational studies. Further biochemical activity based experiments would reveal probable molecular mechanisms of the metal resistance of the novel extremophile. The unique bacteria was identified and named as Exiguobacterium indicum Strain DSAM62.

\section{Conclusions}

From the present study it is concluded that isolated unique Exiguobacterium indicum Strain DSAM62 is highly arsenic tolerant and its efficacy of arsenic uptake is $52.2 \%$ from its respective $\mathrm{LD}_{50}$ dose of arsenic, which will be utilized in arsenic mitigation strategy of agricultural and industrial sludge treatment.16S rDNA sequence of Exiguobacterium indicum Strain DSAM62 was deposited at NCBI GenBank under Accession Number MH819520. Whole genome sequence including plasmid sequence of Exiguobacterium indicum Strain DSAM62 was deposited at NCBI under Accession Number PRJNA555453.

\section{Acknowledgements}

We would like to acknowledge Department of Science \& Technology, Government of West-Bengal for funding this research work. 


\section{Supplementary Tables and Figures}

Table 1. Cell Viability Test by INT Assay

\begin{tabular}{|c|c|c|c|c|}
\hline Name & Condition & Arsenic Concentration & OD Value at 490 nm. With SE & \% of Increase or decrease \\
\hline S6C2 Bacteria & Control & - & $0.179 \pm 0.001$ & - \\
\hline S6C2 Bacteria & Arsenic Treatment & $500 \mathrm{mg} . / 1$ & $0.105 \pm 0.002$ & $41.34 \%$ of decrease \\
\hline S6C3 Bacteria & Control & - & $0.092 \pm 0.003$ & - \\
\hline S6C3 Bacteria & Arsenic Treatment & $300 \mathrm{mg} . / 1$ & $0.039 \pm 0.002$ & $43.35 \%$ of decrease \\
\hline
\end{tabular}

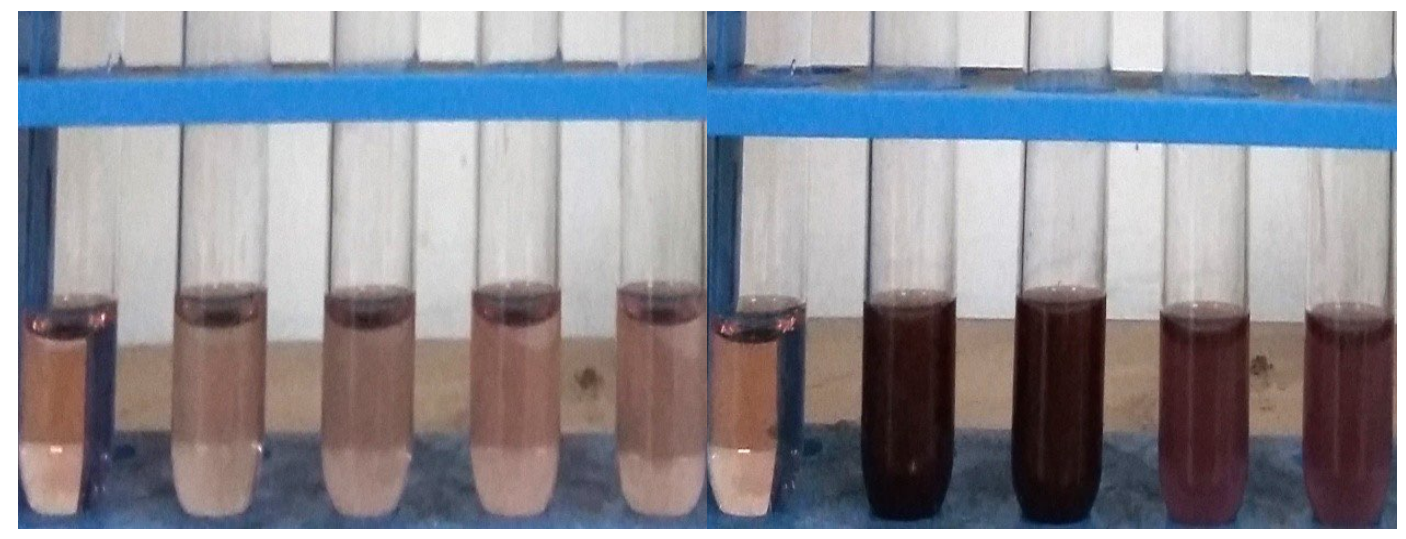

(a)

(b)

Figure 1. (a) and (b). Growth of S6C2 and S6C3 Bacteria in INT supplemented TSB in Control (Second and Third Tube) and Arsenic Treated Condition (Fourth and Fifth Tube) Respectively, (First tube was for Reagent Blank).

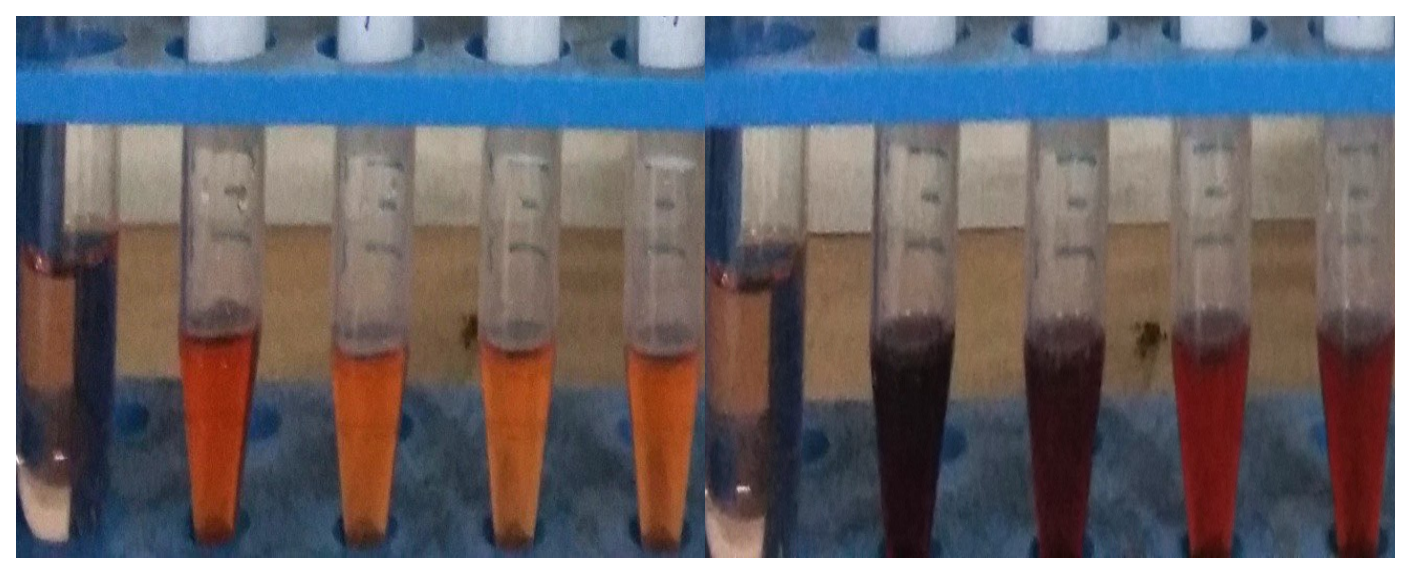

(a)

(b)

Figure 2. (a) and (b). S6C2 and S6C3 Bacterial Viability Test by INT Assay using DMSO in Control (Second and Third Tube) and Arsenic Condition (Fourth and Fifth Tube) Respectively, (First tube was for Reagent Blank). 
Table 2. FAME Results of S6C2 Bacteria by RTBA6 Method

\begin{tabular}{|c|c|c|c|c|c|c|c|c|}
\hline Name of the Organism & $\begin{array}{c}\text { Serial } \\
\text { Number }\end{array}$ & $\begin{array}{l}\text { IUPAC Name of the } \\
\text { Major Fatty Acids }\end{array}$ & $\begin{array}{c}\text { Common Name of the Major } \\
\text { Fatty Acid }\end{array}$ & $\begin{array}{l}\text { IUPAC Name of the } \\
\text { Unique Fatty Acids }\end{array}$ & $\begin{array}{c}\text { Common Name of the } \\
\text { Unique Fatty Acids }\end{array}$ & $\begin{array}{l}\text { Retention time } \\
\text { (Minutes) }\end{array}$ & $\begin{array}{c}\text { ECL } \\
\text { Value }\end{array}$ & Percentage \\
\hline \multirow{18}{*}{$\begin{array}{l}\text { Exiguobacterium indicum } \\
\text { Strain DSAM } 62\end{array}$} & 1. & Iso-C 15:0 & 13-Methyltetradecanoic acid & - & - & 2.3755 & 14.6307 & $20.30 \%$ \\
\hline & 2. & Iso-C $17: 0$ & Not available & - & - & 3.0132 & 16.6342 & $15.07 \%$ \\
\hline & 3. & Anteiso C13:0 & Not available & - & - & 1.8123 & 12.7179 & $11.37 \%$ \\
\hline & 4. & $\mathrm{C} 16: 0$ & Palmitic acid & - & - & 2.8097 & 15.9988 & $9.62 \%$ \\
\hline & 5. & Anteiso C15:0 & Not available & - & & 2.4055 & 14.7275 & $7.98 \%$ \\
\hline & 6. & Iso-C13:0 & Not available & - & & 1.7867 & 12.6215 & $7.36 \%$ \\
\hline & 7. & Anteiso C17:0 & Not available & - & & 3.0431 & 16.7274 & $6.22 \%$ \\
\hline & 8. & - & - & Anteiso C14:0 & $\begin{array}{l}\text { Terminally branched } \\
\text { Myristic Acid }\end{array}$ & 2.1017 & 13.7324 & $0.74 \%$ \\
\hline & 9. & - & - & $\mathrm{C} 10: 03 \mathrm{OH}$ & Not available & 1.4964 & 11.4551 & $0.53 \%$ \\
\hline & 10. & - & - & $\mathrm{C} 18: 3 \mathrm{w} 6 \mathrm{c}(6,9,12)$ & Alpha linolenic acid & 3.3210 & 17.5957 & $0.53 \%$ \\
\hline & 11. & - & - & $\mathrm{C} 18: 12 \mathrm{OH}$ & 2 Hydroxy Oleic acid & 3.8081 & 19.1463 & $0.52 \%$ \\
\hline & 12. & - & - & C16:0N alcohol & Not available & 2.6728 & 15.5713 & $0.45 \%$ \\
\hline & 13. & - & - & $\mathrm{C} 11: 03 \mathrm{OH}$ & Not available & 1.7427 & 12.4555 & $0.38 \%$ \\
\hline & 14. & - & - & Anteiso C16:0 & Anteiso Palmitic Acid & 2.7214 & 15.7233 & $0.36 \%$ \\
\hline & 15. & - & - & $\mathrm{C} 16: 0$ iso $3 \mathrm{OH}$ & $\begin{array}{c}3 \text { Hydroxy } \\
\text { Hexanedecanoic acid/ } \\
\text { Palmitic acid }\end{array}$ & 3.1862 & 17.1743 & $0.33 \%$ \\
\hline & 16. & - & - & $\mathrm{C} 15: 1 \mathrm{w} 5 \mathrm{c}$ & Not available & 2.4681 & 14.92 .92 & $0.25 \%$ \\
\hline & 17. & - & - & $\mathrm{C} 18: 1$ iso $\mathrm{H}$ & Oleic Acid & 3.2854 & 17.4842 & $0.25 \%$ \\
\hline & 18. & - & - & $\mathrm{C} 12: 1$ at $11-12$ & Not available & 1.6042 & 11.9231 & $0.16 \%$ \\
\hline
\end{tabular}


Table 3. Details of Arsenic Metabolism Associated Genes in Exiguobacterium indicum Strain DSAM 62 Genome.

\begin{tabular}{|c|c|c|c|c|c|c|c|c|}
\hline contig_id & type & location & start & stop & strand & evidence_codes & nucleotide_sequence & aa_sequence \\
\hline $\begin{array}{c}\text { PseudoCo } \\
\text { ntig_NC_0 } \\
10556.1\end{array}$ & peg & $\begin{array}{c}\text { PseudoConti } \\
\mathrm{g} \_ \text {NC_01055 } \\
6.1 \_156539 \text { - } \\
158269\end{array}$ & 156539 & 158269 & + & $\begin{array}{c}\text { Efflux ABC } \\
\text { transporter for } \\
\text { glutathione/ } \\
\text { L-cysteine, essential } \\
\text { for assembly of } \\
\text { bd-type respiratory } \\
\text { oxidases => CydD } \\
\text { subunit }\end{array}$ & 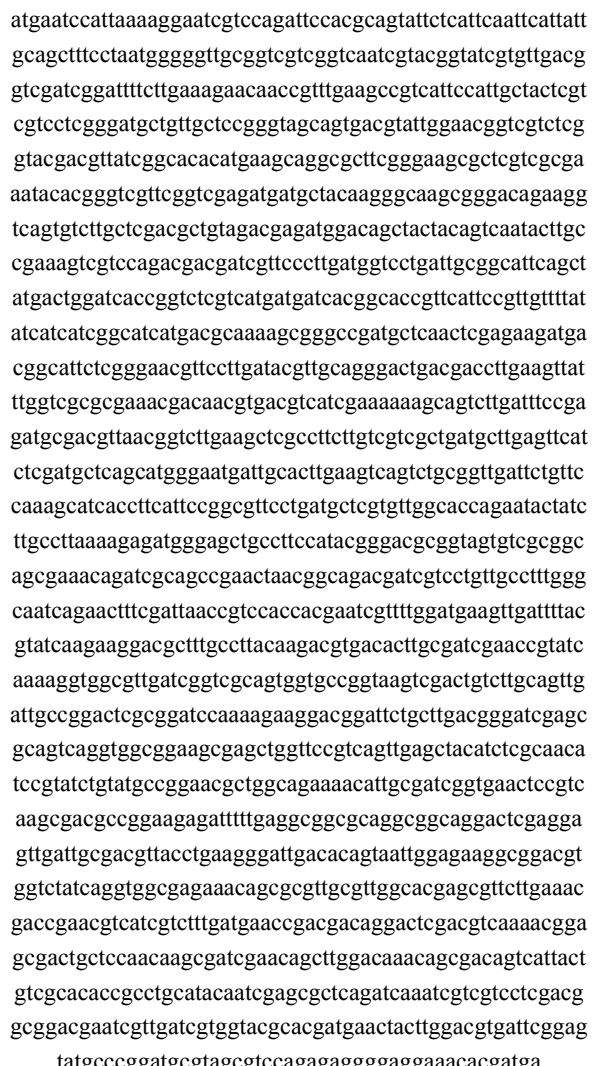 & $\begin{array}{l}\text { MNPLKGIVQIPRSILIQFIIAAFLMGVAVVG } \\
\text { QSYGIVLTVDRIFLKEQPFEAVIPLLLVVLG } \\
\text { MLLLRVAVTYWNGRLGTTLSAHMKQALR } \\
\text { EALVAKYTGRSVEMMLQGQAGQKVSVLL } \\
\text { DAVDEMDSYYSQYLPKVVQTTIVPLMVLI } \\
\text { AAFSYDWITGLVMMITAPFIPLFYIIIGIMTQ } \\
\text { KRADAQLEKMTAFSGTFLDTLQGLTTLKL } \\
\text { FGRAKRQRDVIEKSSLDFRDATLTVLKLAF } \\
\text { LSSLMLEFISMLSMGMIALEVSLRLILFQSIT } \\
\text { FIPAFLMLVLAPEYYLALKEMGAAFHTGR } \\
\text { GSVAAAKQIAAELTADDRPVAFGQSELSIN } \\
\text { RPPRIVLDEVDFTYQEGRFALQDVTLAIEP } \\
\text { YQKVALIGRSGAGKSTVLQLIAGLADPKEG } \\
\text { RILLDGIERSQVAEASWFRQLSYISQHPYLY } \\
\text { AGTLAENIAIGELRQATPEEIFEAAQAAGLE } \\
\text { ELIATLPEGIDTVIGEGGRGLSGGEKQRVAL } \\
\text { ARAFLKRPNVIVFDEPTTGLDVKTERLLQQ } \\
\text { AIEQLGQTATVITVAHRLHTIERSDQIVVLD } \\
\text { GGRIVDRGTHDELLGRDSEYARMRSVQRG } \\
\text { EETR }\end{array}$ \\
\hline
\end{tabular}




\begin{tabular}{|c|c|c|c|c|c|c|c|c|}
\hline \multirow{27}{*}{$\begin{array}{c}\text { PseudoCo } \\
\text { ntig_NC_0 } \\
10556.1\end{array}$} & \multirow{27}{*}{ peg } & \multirow{27}{*}{$\begin{array}{c}\text { PseudoConti } \\
\text { g_NC_01055 } \\
6.1 \_158266 \text { - } \\
159975\end{array}$} & \multirow{27}{*}{158266} & \multirow{27}{*}{159975} & \multirow{27}{*}{+} & \multirow{27}{*}{$\begin{array}{c}\text { Efflux ABC } \\
\text { transporter for } \\
\text { glutathione/L-cystein } \\
\text { e, essential for } \\
\text { assembly of bd-type } \\
\text { respiratory oxidases } \\
\Rightarrow \text { CydC subunit }\end{array}$} & \multirow{27}{*}{ 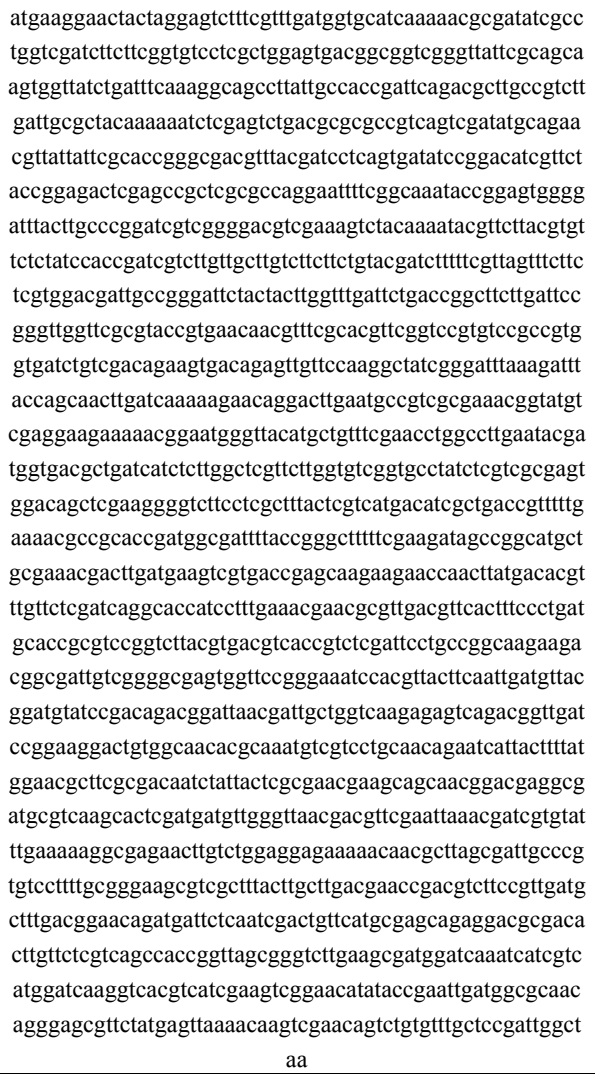 } & \multirow{27}{*}{$\begin{array}{l}\text { MKELLGVFRLMVHQKRDIAWSIFFGVLAG } \\
\text { VTAVGLFAASGYLISKAALLPPIQTLAVLIA } \\
\text { LQKISSLTRAVSRYAERYYSHRATFTILSDI } \\
\text { RTSFYRRLEPLAPGIFGKYRSGDLLARIVGD } \\
\text { VESLQNTFLRVLYPPIVLLLVFFCTIFFVSFF } \\
\text { SWTIAGILLLGLILTGFLIPGWFAYREQRFA } \\
\text { RSVRVRRGDLSTEVTELFQGYRDLKIYQQL } \\
\text { DQKEQDLNAVAKRYVEEEKRNGLHAVSN } \\
\text { LALNTMVTLIISWLVLGVGAYLVASGQLE } \\
\text { GVFLALLVMTSLTVFENAAPMAILPGFFED } \\
\text { SRHAAKRLDEVVTEQEEPTYDTFVLDQAP } \\
\text { SFETNALTFTFPDAPRPVLRDVTVSIPAGKK } \\
\text { TAIVGASGSGKSTLLQLMLRMYPTDGLTIA } \\
\text { GQESQTVDPEGLWQHANVVLQQNHYFYG } \\
\text { TLRDNLLLANEAATDEAMRQALDDVGLTT } \\
\text { FELNDRVFEKGENLSGGEKQRLAIARVLLR } \\
\text { EASLYLLDEPTSSVDALTEQMILNRLFMRA } \\
\text { EDATLVLVSHRLAGLEAMDQIIVMDQGHV } \\
\text { IEVGTYTELMAQQGAFYELKQVEQSVFAPI } \\
\text { G }\end{array}$} \\
\hline & & & & & & & & \\
\hline & & & & & & & & \\
\hline & & & & & & & & \\
\hline & & & & & & & & \\
\hline & & & & & & & & \\
\hline & & & & & & & & \\
\hline & & & & & & & & \\
\hline & & & & & & & & \\
\hline & & & & & & & & \\
\hline & & & & & & & & \\
\hline & & & & & & & & \\
\hline & & & & & & & & \\
\hline & & & & & & & & \\
\hline & & & & & & & & \\
\hline & & & & & & & & \\
\hline & & & & & & & & \\
\hline & & & & & & & & \\
\hline & & & & & & & & \\
\hline & & & & & & & & \\
\hline & & & & & & & & \\
\hline & & & & & & & & \\
\hline & & & & & & & & \\
\hline & & & & & & & & \\
\hline & & & & & & & & \\
\hline & & & & & & & & \\
\hline & & & & & & & & \\
\hline \multirow{11}{*}{$\begin{array}{c}\text { PseudoCo } \\
\text { ntig_NC_0 } \\
10556.1\end{array}$} & \multirow{11}{*}{ peg } & \multirow{11}{*}{$\begin{array}{c}\text { PseudoConti } \\
\text { g_NC_01055 } \\
6.1 \_165288 \_ \\
165917\end{array}$} & \multirow{11}{*}{165288} & \multirow{11}{*}{165917} & & \multirow{11}{*}{$\begin{array}{l}\text { Transcriptional } \\
\text { regulator, AcrR } \\
\text { family }\end{array}$} & atgtcatcttctcaaccagaaaaaatcgataaacgtcatctgcgcacggtgcggac & \\
\hline & & & & & & & acgcgagaaactgttgagtgcggcacgtgacgtcttcttagaacaagggttcaaa & \\
\hline & & & & & & & cggcaacgattcacaagtgattaaacaagcgggcgtcggctacggaacagccta & MSSSQPEKIDKRHLRTVRTREKLLSAARDV \\
\hline & & & & & & & 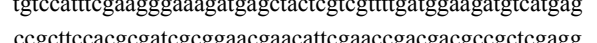 & FLEQGFQTATISQVIKQAGVGYGTAYVHFE \\
\hline & & & & & & & ccgettccacgcgatcgeggaacgaacattcgaaccgacgacgccgctcgagg & GKDELLVVLMEDVMSRFHAIAERTFEPTTP \\
\hline & & & & & + & & $\begin{array}{l}\text { caaaggaacgcatcgtgacgcaagcgacggatttctacgtctcgcggaagaag } \\
\text { acgagcgatattacggattgtcgagcaagcaatcggegtgtcttacatcgtccgt }\end{array}$ & LEAKERIVTQATDFLRLAEEERAILRIVEQA \\
\hline & & & & & & & gcgaaatggaaagcgattcgggaceggttcattgatcggatcagtcaggatatcc & IGVSYIVRAKWKAIRERFIDRISQDIQYAQK \\
\hline & & & & & & & agtatgcgcagaagacaggacttgcgeggcaggatgtcgactcgaaactcgtcg & TGLARQDVDSKLVARGWFFANEMYLFEV \\
\hline & & & & & & & cccgtggttggttctttgcgaatgagatgtatttattcgaagtcgtccgcgaagaggc & \\
\hline & & & & & & & gacagcgacgatcgaagagattgcgcacgtettagcgacgatttatacgcaagga & \\
\hline & & & & & & & ctctaccggatcgaggattga & \\
\hline
\end{tabular}


Table 3 continuous

\begin{tabular}{|c|c|c|c|c|c|c|c|c|}
\hline $\begin{array}{c}\text { PseudoCo } \\
\text { ntig_NC_0 } \\
10556.1\end{array}$ & peg & $\begin{array}{c}\text { PseudoConti } \\
\text { g_NC_01055 } \\
6.1 \_370367 \text { - } \\
370816\end{array}$ & 370367 & 370816 & + & $\begin{array}{l}\text { Universal stress } \\
\text { protein family }\end{array}$ & $\begin{array}{l}\text { atggagagccagtatcatacgattttagtggcagtcgatggatcaaagacggcag } \\
\text { atcttgcctttgaaaaggcagtgaaattcgctaaactcgatcatgccaaactcgtcat } \\
\text { cgctcatgtcattgatattcagacatttgctaatgtacgtgccaataagcgtttcattga } \\
\text { tcaaaacgtcacggaatatgcacaaggactgctcgatcgttacgagaagcgggca } \\
\text { cgagaagaaggcgtcgagacaattgaactggtcatcgaaaatggctctcccaaaa } \\
\text { cattgattccgaaggtcatcgcaccacgtgtcggtgctgggttgatcgtctgcggg } \\
\text { gcggtcgggatgaatgcgatggaacgcatcatgatcgggagtgtctctgaaaaca } \\
\text { tctccegttatgcgaaatgcgatatctatatcgtccgtccgaaaaccttgaagtga }\end{array}$ & $\begin{array}{l}\text { MESQYHTILVAVDGSKTADLAFEKAVKFA } \\
\text { KLDHAKLVIAHVIDIQTFANVRANKRFIDQ } \\
\text { NVTEYAQGLLDRYEKRAREEGVETIELVIE } \\
\text { NGSPKTLIPKVIAPRVGAGLIVCGAVGMNA } \\
\text { MERIMIGSVSENISRYAKCDIYIVRPKTLK }\end{array}$ \\
\hline $\begin{array}{c}\text { PseudoCo } \\
\text { ntig_NC_0 } \\
10556.1\end{array}$ & peg & $\begin{array}{c}\text { PseudoConti } \\
\text { g_NC_01055 } \\
6.1 \_378282 \text { - } \\
379592\end{array}$ & 378282 & 379592 & + & $\begin{array}{l}\mathrm{ABC} \text { transporter, } \\
\text { substrate-binding } \\
\text { protein (cluster } 1, \\
\text { maltose/g3p/polyami } \\
\text { ne/iron) }\end{array}$ & $\begin{array}{l}\text { atgaaattcaaaaaaacgaaactcgttgctgcagcatctgtcctgacattatccgcat } \\
\text { tccttgctgcttgtggtggagaagatgagcaacaaacgaaacgaaagacggtaa } \\
\text { gacgatcgtcacatggtggggetgggcgccacaacctgaagcggggaaagcag } \\
\text { tcgttgatgcgttcaacgaatcgcaagacaaatacgtcgttcaattcaaacgctaca } \\
\text { gtgaagactatgaaaaacaattacaagtcgcgatgttgtcaggtaagggtccagac } \\
\text { atcatcggtctaaaagaaccgatgatccaacagtacaaggatcgtgtcgtaccggt } \\
\text { tgattcgtacatggataaagcagccggcaaaggctggaaagataagttcgtcgag } \\
\text { cttggaattgaacagacgacactcgacggtaaacaatacgcggtcccaatcggttt } \\
\text { cacaggtcaagcgtacttgatgtacaacaagacgatgctcgacaaatatggcgtg } \\
\text { acaccaccgaagaactacaaagaaacagtcagcgcaatcaagaagattaaagac } \\
\text { tcaggcgataaagtcatcccactcatgctcggagcaaaagatgcgtggatcgatat } \\
\text { cgacgtctacaacgtcctcagtcaccaagtggcgccaggttacatccaaaaagttc } \\
\text { tttcgggtgaagcgaagtggacagacgacgagatggtcaaaacagcacaaatct } \\
\text { ggcaagaccttttaaggataaagttttccaagaaggtgcacttggtctagcgacat } \\
\text { acaatgacgggatgaaccaattcttcgataaaaaagcagcgatgtgggtcatcggt } \\
\text { tcatgggaagcgcactcgatgacgacgaaagagaaaaaagaaaaatggaaaatc } \\
\text { gatgatgagctcggattcgttccactcccgaacttagcaggcggaacagagcaac } \\
\text { ccgtcatcgcatcgatcgacatggcacttggtgtcaacaaagagtcaaaacaaca } \\
\text { agaaggtgcagcggagttcatcgccttcatgagccaaggaaaaggacaagaagt } \\
\text { ctacatgggtgagttcgagatggcacctggcatcaaggacgtcaaagtcgattca } \\
\text { gatgctgcttcacatcggaaggtgaaaaagagtcgtacaagatgttgaacgaca } \\
\text { cattagcaaaagcggttgctagccgtggtatccgggatacgaaattaaacgatatc } \\
\text { ctcggtaaggaacttcaaaacatcgcgacaggacaagatccgaaagaagcattac } \\
\text { aacgcgttcaagacgcagcggatcaatcagcgaaataa }\end{array}$ & $\begin{array}{c}\text { MKFKKTKLVAAASVLTLSAFLAACGGEDE } \\
\text { QQTKTKDGKTIVTWWGWAPQPEAGKAVV } \\
\text { DAFNESQDKYVVQFKRYSEDYEKQLQVA } \\
\text { MLSGKGPDIIGLKEPMIQQYKDRVVPVDSY } \\
\text { MDKAAGKGWKDKFVELGIEQTTLDGKQY } \\
\text { AVPIGFTGQAYLMYNKTMLDKYGVTPPKN } \\
\text { YKETVSAIKKIKDSGDKVIPLMLGAKDAWI } \\
\text { DIDVYNVLSHQVAPGYIQKVLSGEAKWTD } \\
\text { DEMVKTAQIWQDLFKDKVFQEGALGLAT } \\
\text { YNDGMNQFFDKKAAMWVIGSWEAHSMT } \\
\text { TKEKKEKWKIDDELGFVPLPNLAGGTEQP } \\
\text { VIASIDMALGVNKESKQQEGAAEFIAFMSQ } \\
\text { GKGQEVYMGEFEMAPGIKDVKVDSDAAF } \\
\text { TSEGEKESYKMLNDTLAKAVASRGIRDTK } \\
\text { LNDILGKELQNIATGQDPKEALQRVQDAA } \\
\text { DQSAK }\end{array}$ \\
\hline $\begin{array}{c}\text { PseudoCo } \\
\text { ntig_NC_0 } \\
10556.1\end{array}$ & peg & $\begin{array}{c}\text { PseudoConti } \\
\text { g_NC_01055 } \\
6.1 \_413828 \text { - } \\
413229\end{array}$ & 413828 & 413229 & - & $\begin{array}{l}\text { Transcriptional } \\
\text { regulator, ArsR } \\
\text { family }\end{array}$ & $\begin{array}{l}\text { atggaacaaaaagcgattcacatattagagagctatgaacagttaaaagtgatcag } \\
\text { tgatccgttacgaacaaaaatccttatgtttctcgtcgaaaaaccacacacggtacat } \\
\text { cagttagcccacttgctgacgttatctcgcgcgaaggtcctctatcacgtacgggaa } \\
\text { cttgaaaagcatgacttgattcgtctcgtccggacggaagaacagggcggcaatct } \\
\text { attgaaatactatcaagcgattgctcgaggatacattcctgccgatcatctactgaac } \\
\text { ttcgtcgagacgaatgaagcgacceggcagtcgtatctcgaagtattggaccggg } \\
\text { caaagacacgcgttcttacggctccgacagctacttttctcttcatctccgaacgt } \\
\text { cgaggactggatgagcttatcacttcaaaaggaactgacgatgtttgaagccgact } \\
\text { ttcaacgctttgctacaaaatatcgtgctctattggacgagttcacacggtctccttca } \\
\text { ctagacaaaaagataaaaacacttctatatcatgacgactgccttcgcaattgat } \\
\text { gaaccactgtttgagaacgacgaggtctaa }\end{array}$ & $\begin{array}{c}\text { MEQKAIHILESYEQLKVISDPLRTKILMFLV } \\
\text { EKPHTVHQLAHLLTLSRAKVLYHVRELEK } \\
\text { HDLIRLVRTEEQGGNLLKYYQAIARGYIPA } \\
\text { DHLLNFVETNEATRQSYLEVLDRAKTRVL } \\
\text { TAPTATFSPSSPNVEDWMSLSLQKELTMSE } \\
\text { ADFQRFATKYRALLDEFTRSPSLDKKDKK } \\
\text { HFYIMTTAFAIDEPLFENDEV }\end{array}$ \\
\hline
\end{tabular}


Table 3 continuous

\begin{tabular}{|c|c|c|c|c|c|c|}
\hline $\begin{array}{l}\text { PseudoCo } \\
\text { ntig_NC_0 }\end{array}$ & peg & $\begin{array}{l}\text { PseudoConti } \\
\text { g_NC_01055 } \\
6.1 \_482465\end{array}$ & 482465 & 485041 & + & $\mathrm{ClpB}$ protein \\
\hline
\end{tabular}

isu;Proteol ysis_in_ba cteria,_AT

P-depende nt

isu;USS-D B-7

icw(1);Pro tein_chape rones

isu;Type

VI_secreti

on_system

atggatttgaacgtttaacggatcgggcacacgagggaatcgtctctgcccaagcgatcgeg aaacaacgtcgtcatagtgaaatcacagaatggcatttgttacttgccttacttgctcaagaaga agggattgcacgagtcgtctttgaaaagttgaatcaacggattgagacattgaatggagcgatt gacgaggcgatcggtaagcttcctgccttgtcccaggcgacgacgcctcggatcgggggct cgttgctgaacgtgttgacggaagcagagacggaagcgcgtctcatgcaggatgactatgtc tccgtcgaacacttattgttagcattgatcaaacaatcaagtccagcagctcagtacctacgtcg tcaaggcatcacggaagagacactccgggaagcgatcgtcagtatgcgaggcaatcggaa ggtgacgacgaaaaatcctgaagagacgtttgatgtgctgaaaaaatatggacgtgatctcgt agcggatttccggtccgggaaaacagatccggtcatcggecgtgatgatgagattcgacgtg tcatccggattttgagtcggaagacaaaaaacaatcccgtcttgattggagaacccggtgtcg ggaaaacggcaatcgttgaaggactcgcgcaacggatcgtccgaggggatgtaccggaga gtctgaaaaacaagcagttgttcagtttagacatgagtgcgctcgtcgctggtgcgaagtacc ggggtgagttcgaagaacgcctgcaagcagtcttgaatgaagtcaaggaagccgaaggaca gattctcttattcatcgatgagctgcatacgatcgttggtgccggaaagacggacggegcaat ggatgccggaaacatgctcaagccgatgcttgcacgaggagaattgcactgtatcggtgcga cgacgctggatgagtaccggaagtatatcgaaaaggacccggcgetcgaacgtcgettcca acaagtcctcgtcgcggaaccggatgtcgaggatacgatttccattctgcgtggattaaaaga acgattcgagattcaccacggtgtgcggattcatgataatgcgctcgtcgcggcggcgatgtt atccgatcggtatatcacggatcgattcatgccggataaggcgatcgatctcgtcgatgaagc atgtgcgatgattcggaccgatatggagtcaatgccagctgaactcgattcactcgttcgtcgg gtcatgcagctcgaaatcgaggaagcggcattaaagaaagagacggatgaagcatcccgg aaacgacttgccgtcttacagcaagaactcagctctgtccgggaagacgagagtgcgctgcg gacacgatgggaacgggaaaaagagagttcgcaaagtgtccaacagttacgcgcggatctt gagaaggcaaaactggcattacaagaagcggaagggcgctatgacttgaaccgagcatcg gaaatcaagtacggtcaaattccggatcttgaggcacgactgaaagtcgcggaagagtcatct gaacacgtctcacacgaactcgttcgagaagcggtgacggaagaagagatatccgacatcg tttcgaaatggactggcattccggtgacgcggcttgcgcagggcgaacgcgaaaaattacttt atcttgaagatacgcttcatgagcgcgtcttcggtcaagacgaagcggttcgtctcgtcgcgg acgctgtcattcgagcgcgcgcgggcatcaaggatccgaaccgcccgattggctcgttcttgt tcetcggtccgacaggggtcgggaagacagaactcgccaaagcettagcggcggegatgtt cgatagtgaagatcatatcgtccgcatcgatatgtcggagtatatggaaaaacacaatgtctcc cgtctcgtcggtgcgcctccgggatatgtcggttatgaagaaggcggtcaattgacggaagc cgtccgacggagcccgtattcagtgctgttgttgatgagatcgaaaaagcgcacggagacgt ctttaatatcttgcttcagttgctcgatgatggtcgactgacggatgcgcaaggacgtgtcgtcg acttcaagaacacgatcgtcatcatgacgtcaaacatcggggcaccaatcctgcttgaagcag caaaagatggtgtcatcgatgcagcggaagaagaagccgttcgccaagaactgaagcgcca cttccgaccggagttcttgaaccggatcgatgatacgattttattccatccactccaccggacg gaaatcgaacgaatcatcgacaaagcggtcgaaaaaatgagttcacgtttatctggacgtggc attacgattgatgttacggatgctgcgaagacgttgattttcgaagaagcettcgaaccacaata cggcgcacgtccaatcaatcgctatatgcaacgaacgattgagacgaaacttgccegtgcctt gatcagtggggcgatacaagatggtgcccggattgcgettgacgtagaagacggcgaactg

MAKDYYQTLGVTKDASNQDIKRAYRKLA KQYHPDVNKEASADQRFKDIQEAFDVLGD EQKRAQYDRYGSNFDQMAGAGAGGAGD YEDLFRQFGGGGRTRPGQSFGFEDMFGSFF SQEEVSTDEELELTVPLGHLSTNEKVTVRL ATGSIQLTLPKDVYDGKKVRLRGKSSMRN RQGVAGDVYVTIHLKDDDQFRRVDQDVIS TVRVHPTTLVLGGEVVADTLEGKRIKLKV KPGTKPGARLRIPNRGLSQANGHRGALLY QLEVKLPEMDRAFYEEWERQLAVKE 


\begin{tabular}{|c|c|c|c|c|c|c|c|c|c|}
\hline $\begin{array}{c}\text { PseudoCo } \\
\text { ntig_NC_0 } \\
10556.1\end{array}$ & peg & $\begin{array}{l}\text { PseudoCo } \\
\text { ntig_NC_0 } \\
10556.1 \_7 \\
82930 \_783 \\
418\end{array}$ & 782930 & 783418 & + & Thioredoxin & $\begin{array}{c}\text { idu(2);CBSS- } \\
\text { 315749.4.peg } \\
.3658 \\
\text { idu(2);Glycin } \\
\text { e_reductase, } \\
\text { sarcosine_red } \\
\text { uctase_and_b } \\
\text { etaine_reduct } \\
\text { ase }\end{array}$ & $\begin{array}{c}\text { gtgtcaaagaagtcgaaacgtaaaaacacgaaaaaaccgcaatccaaggcgaattggattacag } \\
\text { cgggagtcatcgccttgatcgtattggtgggaggattacttctcgtcttcacggatcgagaagattc } \\
\text { tgcatcgaagaacggcaacctaacggctacacaagtcgcagataaagtaaaatccggtgatgaa } \\
\text { ttctatacgtatttctaccaaacgggttgtgttcactgtgaaaaagtaaaaccatatctcgtccgett } \\
\text { ggtgaaaaacaagacattccgttcgaacagatcgatcttgctgtcgagcagtcggcttgggatac } \\
\text { gtttggcatcgagggtacaccaactgtcgttcactttaaagacggtaaagaagtcggacgcgtag } \\
\text { caggtgaacaaacagaagacagctataaagagttctcgctggaaaagacgtaaaggactcaaa } \\
\text { agaagaatcatctggtgatctcaatgattaa }\end{array}$ & $\begin{array}{c}\text { MDFERLTDRAHEGIVSAQAIAKQRRHSEITEWHL } \\
\text { LLALLAQEEGIARVVFEKLNQRIETLNGAIDEAIG } \\
\text { KLPALSQATTPRIGGSLLNVLTEAETEARLMQDD } \\
\text { YVSVEHLLLALIKQSSPAAQYLRRQGITEETLREAI } \\
\text { VSMRGNRKVTTKNPEETFDVLKKYGRDLVADFR } \\
\text { SGKTDPVIGRDDEIRRVIRILSRKTKNNPVLIGEPG } \\
\text { VGKTAIVEGLAQRIVRGDVPESLKNKQLFSLDMS } \\
\text { ALVAGAKYRGEFEERLQAVLNEVKEAEGQILLFI } \\
\text { DELHTIVGAGKTDGAMDAGNMLKPMLARGELH } \\
\text { CIGATTLDEYRKYIEKDPALERRFQQVLVAEPDVE } \\
\text { DTISILRGLKERFEIHHGVRIHDNALVAAAMLSDR } \\
\text { YITDRFMPDKAIDLVDEACAMIRTDMESMPAELD } \\
\text { SLVRRVMQLEIEEAALKKETDEASRKRLAVLQQE } \\
\text { LSSVREDESALRTRWEREKESSQSVQQLRADLEK } \\
\text { AKLALQEAEGRYDLNRASEIKYGQIPDLEARLKV } \\
\text { AEESSEHVSHELVREAVTEEEISDIVSKWTGIPVTR } \\
\text { LAQGEREKLLYLEDTLHERVFGQDEAVRLVADA } \\
\text { VIRARAGIKDPNRPIGSFLFLGPTGVGKTELAKAL } \\
\text { AAAMFDSEDHIVRIDMSEYMEKHNVSRLVGAPPG } \\
\text { YVGYEEGGQLTEAVRRSPYSVLLFDEIEKAHGDV } \\
\text { FNILLQLLDDGRLTDAQGRVVDFKNTIVIMTSNIG } \\
\text { APILLEAAKDGVIDAAEEEAVRQELKHFRPEFLN } \\
\text { RIDDTILFHPLHRTEIERIIDKAVEKMSSRLSGRGIT } \\
\text { IDVTDAAKTLIFEEAFEPQYGARPINRYMQRTIET } \\
\text { KLARALISGAIQDGARIALDVEDGELVVHG }\end{array}$ \\
\hline $\begin{array}{c}\text { PseudoCo } \\
\text { ntig_NC_0 } \\
10556.1\end{array}$ & peg & $\begin{array}{l}\text { PseudoCo } \\
\text { ntig_NC_0 } \\
10556.1 \_7 \\
98111 \_799 \\
256\end{array}$ & 798111 & 799256 & + & $\begin{array}{l}\text { Hypothetical } \\
\text { radical SAM } \\
\text { family enzyme in } \\
\text { heat shock gene } \\
\text { cluster, similarity } \\
\text { with CPO of BS } \\
\text { HemN-type }\end{array}$ & & 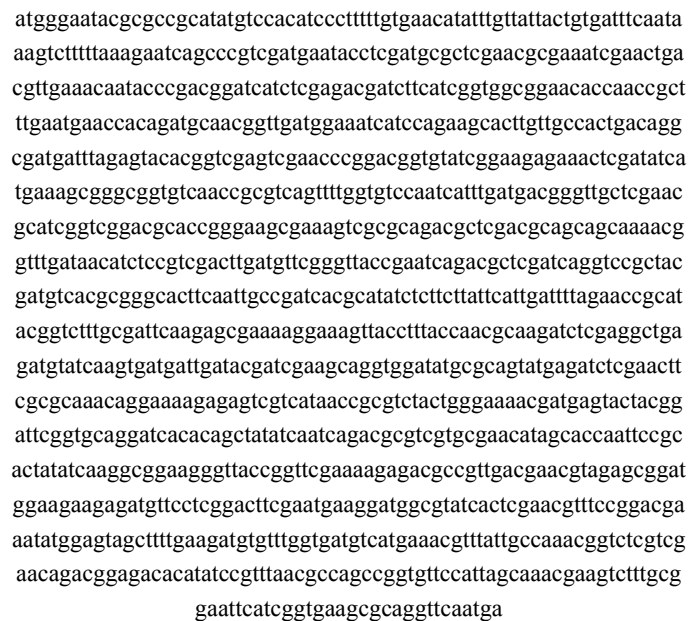 & $\begin{array}{c}\text { MSKKSKRKNTKKPQSKANWITAGVIALIVLVGGL } \\
\text { LLVFTDREDSASKNGNLTATQVADKVKSGDEFYT } \\
\text { YFYQTGCVHCEKVKPYLVPLGEKQDIPFEQIDLA } \\
\text { VEQSAWDTFGIEGTPTVVHFKDGKEVGRVAGEQ } \\
\text { TEDSYKEFFAGKDVKDSKEESSGDLND }\end{array}$ \\
\hline
\end{tabular}




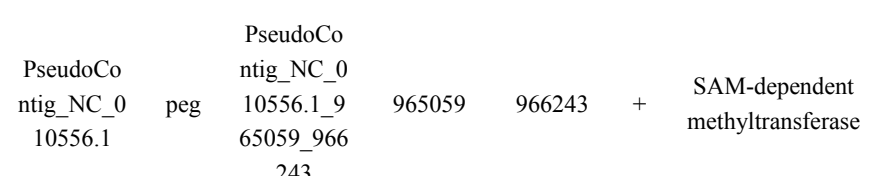

243
PseudoCo

PseudoCo

ntig_NC_0

10556.1
ntig_NC_0

peg 10556.1_

217221_12

17535
Arsenical

$12172211217535+$ resistance operon

repressor ttgatcgagacagcaaaacgggtagaagagatgagtcagttcttgaagctactgagcgatggaacacgtcttgaaatttt ctaaaattattgcgtcaatcccagctcatcttggaacgacgggaacgacaatggatttatttcgaatcaatccagatca cacaacacagattgttattgacgattttagaagaaatggacatgccggacatcccggatagaagttgctaa gcgaagactacacgttcgggagcattgtgtctgtgatttcgtcgagatgtttgatattcgcaaccggcagtcagtcgtcat gtggaactacatgaattaaaagcgagtcttgcctcgcaaattacgcaaggaacactgatccatgcaacgataagtaatcc gcgtcaaaaatcaaatgatctccgacgaatcaaggtaaaaccgattctattaagagatacggtgatgatgcaggtagagtt tcaatttgaacgcgttatgaagcatgaaaatattttagtggacgatttcgtcgggegactcgatgactggttcacggaattcc gccaattcttattccgtttgaagaagaggaatggcagttccagctctcgaaaaagctgaaagtcgcgctcaagacatcca aaaaagagccgatgaaagctctcttgtcgcatgaccgcaaaaaacctatctattagaagacggtgtaccggttccgtttc tgattcgcttaggcgtcatgacggaagcgggtcaagtcaaaaaacagaagtacgataagtttaacaaatcaatcgetttc ttgaattcgtcgaggatagcatcgctgccttgccaaaaggaaaaaaactccggatcttggacttcggatgcgggaagtcg tatttgacgtttgctctctatcattatctaaaagtcgtcaaaggattcgacctcgaagtgacaggtcttgatttaaagaaagaa gtcatcgaagaatgtacacaaattgcgcotgatctggattataccgatctgacattccgtgtcggagacgttcatgattaca caggggagacggaagtcgacctgatggtgacacttcacgettgtgatgtcgcaaccgacgtcgcactcgcacgagctg ttgactggaatgcatcggtcatcctgagcgtaccgtgctgtcaaaaggaattgaaccgtcaactggactgttcgccactcg atgtcatgctccagcacggactgatcaaagaaaaattcgcgtcactggcgacagactcgattcgtgccgagttgctgacg ctcgtcggatacgaagcgcagttgctcgaattcatcgatctcgagcacacaccgaagaacatcttgattcgcgcgtataa acaaaacaagcgaccaacggaagagaaaatcgaccgctacatcgcgttccgtgatttgttgcatgcccgaccatttttag aaactgaattaagcggcagacttggacagatttcaccgaaactcgtacaataa
MGIRAAYVHIPFCEHICYYCDFNKVFLKNQP VDEYLDALEREIELTLKOYPTDHLETIFIGGGT PTALNEPQMQRLMEIIQKHLLPLTGDDLEYT VESNPDGVSEEKLDIMKAGGVNRVSFGVQSF DDGLLERIGRTHREAKVAQTLDAAAKRFDNI SVDLMFGLPNQTLDQVRYDVTRALQLPITHIS SYSLILEPHTVFAIQERKGKLPLPTQDLEAEM YQVMIDTIEAGGYAQYEISNFAQTGKESRHN RVYWENDEYYGFGAGSHSYINQTRRANIAPI PHYIKAEGLPVRKETPLTNVERMEEEMFLGL RMKDGVSLERFRTKYGVAFEDVFGDVMKRL LPNGLVEQTETHIRLTPAGVPLANEVFAEFIG EAQVQ

MELHELKASLASQITQGTLIHATISNPRQKSN DLRRIKVKPILLRDTVMMQVEFQFERVMKHE NILVDDFVGRLDDWFTEFRQFLFRFEEEEWQ FQLSKKLKVALKTSKKEPMKALLSHDRKKT YLLEDGVPVPFLIRLGVMTEAGQVKKQKYD KFKQINRFLEFVEDSIAALPKGKKLRILDFGC GKSYLTFALYHYLKVVKGFDLEVTGLDLKK EVIEECTQIARDLDYTDLTFRVGDVHDYTGE TEVDLMVTLHACDVATDVALARAVDWNAS VILSVPCCQKELNRQLDCSPLDVMLQHGLIKE KFASLATDSIRAELLTLVGYEAQLLEFIDLEH TPKNILIRAYKQNKRPTEEKIDRYIAFRDLLH ARPFLETELSGRLGQISPKLVQ

gtgaacgcattgaccggtacacatttactagcgatcggaatttttctgatcaccttattcttaatcattaaacaaccgaaagg actcggcatcggttactccgcgatgggaatggcgetcgttgcgctattgacgggagtcgtcaacctcgaggatgtctcga cggtctggggcatcatctggaatgccacctttacttcatcgettetgatcatcatctcattgattcttgatgagattgggttcttc gaatgggcggcactccatatggcacgcatcgcacgaggtggtggtgtcaaactattcgtgtacatgacattactcggtgc tgtcgttgctgctttattcgcgaacgatggggcagccttgattctgacaccaatcgtcctcgcgatggttcgtcacttgaaac ttccggattatgtcgtgttagcttacgtettcgettceggattcattgccgatacagccagtttgccgttcgtcgtctcgaacet cgtcaacatcgtctcagcagacttctttaacatcgggtttacggagtatgcgtcacggatggtgttcgttaatctcttttctgtc atcggcagtctgatcgtcttgtatctctatttccgaaagagtattccaaagaattacgatgtcgcgcaactcgtcgcacccg cgacagcgatcaaggatcaacggatgtttaagctttcatggttcgtcctcatttgettgtcgttggatactttacgagtgacg tcatcggcattccegtcagtcttgtcgetggaatcatcgetttgttcttettattgatggcacgccgttcaccgagcgtaccga cgaaaaaggtcatcggtggtgcaccgtgggcgatcgtcttctttcacttggcatgtacatcgtcgtctacggactgcaaa atgccgggttgacacaagtactcgctgacatcattgatggctttgcaacgaatttagcagccgcaacatttggcatgggct tettggctgccatcttgtcgtcgatcatgaataatatgccgaccgtcatgatcgatgccettgcgatcgacttgagccaggc aactggaacgattcgagaagcgctcatctatgcgaacgtcatcggatctgatcttggaccgaagatcacgccaatcggta gtctagcgacattactttggttacacgtgcttcggacgaaaggcgtgaagattggttgggggcaatactttaagattggaa cgattctgacgatcccgacacttgccatcacattacttggcttgtatatcagcttggtactttattga 


\begin{tabular}{|c|c|c|c|c|c|c|c|c|c|}
\hline $\begin{array}{c}\text { PseudoCo } \\
\text { ntig_NC_0 } \\
10556.1\end{array}$ & peg & $\begin{array}{c}\text { PseudoCo } \\
\text { ntig_NC_0 } \\
10556.1 \_1 \\
238155 \_12 \\
39072\end{array}$ & 1238155 & 1239072 & + & $\begin{array}{c}\text { Efflux ABC } \\
\text { transporter, } \\
\text { ATP-binding } \\
\text { protein }\end{array}$ & & $\begin{array}{l}\text { atgattcatgtcgagaacttgacgaagacgtacgatggaaaagatgtcgtcaaaggcatctcgttcgat } \\
\text { gtcgaggcaggagaaatctttgcttttctaggaccgaacggagcaggaaaatcaacgaccgtccaga } \\
\text { tgctgacgacgttgattccgatttccggtggtcgggcgacgattcaagaatttgatgtcgtcaacagg } \\
\text { aaaaacaggttcgcttgcaaatcggagttgcttgcaagataccggcatcgatgaggattaaccggg } \\
\text { cttgaattactcgtcctacaaggaaaattattcggattaagtcagacggaagcaaaaatacgggcaga } \\
\text { ggaattactacgactcgtcggactcgatcaagacggcaagcgtcggtcaggcacttactccggcgg } \\
\text { gatgaaacgacggcttgatctagcgttgacgctcgtccatcaaccgaccgtttttttctcgacgaacc } \\
\text { aacgaccggacttgacccggcgagtcgtttgcaaatctggaacgaggtccggcgactgaacgaag } \\
\text { agttcggaacgacgatcttttgacgacacagtacttggaagaggccgatcagctagccgaccggat } \\
\text { cgcgatcatcaatgaagggcaactgattgccgaagggacggcagctgagctgaaggcagcaaacg } \\
\text { gagaagagcggatcgaattgacacttgcggaaaaagaggacgaacaaatcgttttagagacgtttgc } \\
\text { cggtcgtcaggaaaaagaccgttcgtcattccttcgcggggaacggagacactgcgcgcggtcgt } \\
\text { cegtttctcgatgaacggaagatggttgcgacgtcactggtcgtcaaacaaccgtcacttgatgatgt } \\
\text { cttcattcgtttgaccggacaagcttataaggaggaatcgtga }\end{array}$ & $\begin{array}{c}\text { MNALTGTHLLAIGIFLITLFLIIKQPKGLGIGYS } \\
\text { AMGMALVALLTGVVNLEDVSTVWGIIWNAT } \\
\text { FTFIALIIISLILDEIGFFEWAALHMARIARGGG } \\
\text { VKLFVYMTLLGAVVAALFANDGAALILTPIV } \\
\text { LAMVRHLKLPDYVVLAYVFASGFIADTASLP } \\
\text { FVVSNLVNIVSADFFNIGFTEYASRMVFVNLF } \\
\text { SVIGSLIVLYLYFRKSIPKNYDVAQLVAPATAI } \\
\text { KDQRMFKLSWFVLILLVVGYFTSDVIGIPVSL } \\
\text { VAGIIALFFLLMARRSPSVPTKKVIGGAPWAI } \\
\text { VFFSLGMYIVVYGLQNAGLTQVLADIIDGFA } \\
\text { TNLAAATFGMGFLAAILSSIMNNMPTVMIDA } \\
\text { LAIDLSQATGTIREALIYANVIGSDLGPKITPIG } \\
\text { SLATLLWLHVLRTKVKIGWGQYFKIGTILTI } \\
\text { PTLAITLLGLYISLVLY }\end{array}$ \\
\hline $\begin{array}{c}\text { PseudoCo } \\
\text { ntig_NC__0 } \\
10556.1\end{array}$ & peg & $\begin{array}{c}\text { PseudoCo } \\
\text { ntig_NC_0 } \\
10556.1 \_1 \\
697908 \_16 \\
97198\end{array}$ & 1697908 & 1697198 & - & $\begin{array}{l}\text { SAM-dependent } \\
\text { methyltransferase }\end{array}$ & & 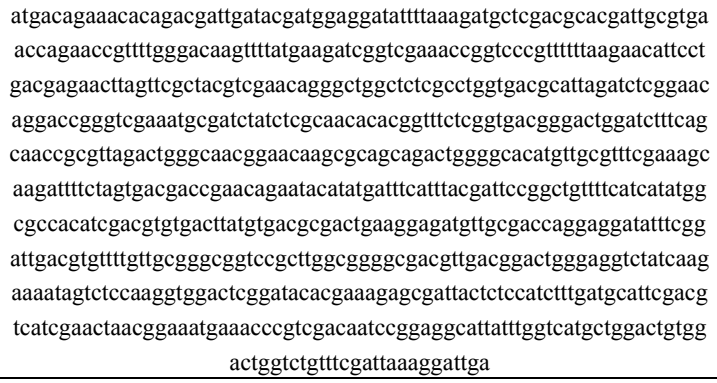 & $\begin{array}{c}\text { MIHVENLTKTYDGKDVVKGISFDVEAGEIFA } \\
\text { FLGPNGAGKSTTVQMLTTLIPISGGRATIQEF } \\
\text { DVVKQEKQVRLQIGVALQDTGIDEDLTGLE } \\
\text { LVLQGKLFGLSQTEAKIRAEELLRLVGLDQD } \\
\text { GKRRSGTYSGGMKRRLDLALTLVHQPTVLFL } \\
\text { DEPTTGLDPASRLQIWNEVRRLNEEFGTTIFL } \\
\text { TTQYLEEADQLADRIAIINEGQLIAEGTAAEL } \\
\text { KAANGEERIELTLAEKEDEQIVLETFAGRQEK } \\
\text { DRLVIPSRGTETLRAVVRFLDERKMVATSLV } \\
\text { VKQPSLDDVFIRLTGQAYKEES }\end{array}$ \\
\hline $\begin{array}{c}\text { PseudoCo } \\
\text { ntig_NC_0 } \\
10556.1\end{array}$ & peg & $\begin{array}{c}\text { PseudoCo } \\
\text { ntig_NC_0 } \\
10556.1 \_1 \\
882552 \_18 \\
81563\end{array}$ & 1882552 & 1881563 & - & $\begin{array}{c}\text { Thioredoxin } \\
\text { reductase (EC } \\
1.8 .1 .9)\end{array}$ & $\begin{array}{l}\text { idu(3);pyrimidi } \\
\text { ne_conversions } \\
\text { idu(3);Thioredo } \\
\text { xin-disulfide_re } \\
\quad \text { ductase } \\
\text { idu(3);Glycine_ } \\
\text { reductase,_sarc } \\
\text { osine_reductase } \\
\text { and_betaine_r } \\
\text { eductase }\end{array}$ & $\begin{array}{l}\text { atgttagattgtatcgtaatcggtgcaggaccgtgtgggttatcggcagcgatcgaaatgcaagatcg } \\
\text { gggactggacgtcgaagtgctcgaaaagggaaatatcgtcgaagcgatctatcgttatccgacgcat } \\
\text { caaacgttctttcaagtagtgagaagttagaaattggtggtgtaccgttcatcaataaagaattaaaacc } \\
\text { gcgacgtctcgacgcgctcgtctattatcgagaagtcgtcaaacgaaaacaattgacgattcgtccgtt } \\
\text { tgagacggtcgagcggattgaacgtcaagcggatcattttatcatccactcggagcgttccggggaa } \\
\text { aaaagaagccgagaagctcgctccgtcgtgcttgcgacaggttattatggtttaccaaaccggatgga } \\
\text { tgttcctggagaggaattacctcatgtctcgcactactttacggaaggacatccgtatttgatcaagatg } \\
\text { ttgtcgttatcggtggaaaaaattcgagcgttgatgcagcgattgaacttgaaaagcaggagcacgt } \\
\text { gtgaccgtcctttaccgtggaccggagtatagtccatccatcaaaccatgggtgttgccgaacttcgaa } \\
\text { tctctcgttcgttcggaaaggtcaagatgatttttggggcgtcaatcgaagaaattacggagcaagag } \\
\text { gtcgtttatcaaatagatggagataaacagaccgtccgtgctgattttgtttttgcgatgacaggttacac } \\
\text { acccgatgtcggattgttcgctgacacgggcattatgattgatcgtaaacaggtattccaagtcacga } \\
\text { cgaagagacgatggaatcgaatgtcccgggcatctatatcgcaggtgtcgtcgcagcaggatatgac } \\
\text { gccaataaaatattcattgaaaacggacgtttcacggtgcaagcattgccaaccatctcgttgaacgg } \\
\text { ctacgtggtgcatcgatacaggcctaa }\end{array}$ & $\begin{array}{c}\text { MKKWFVILMLIPVTLLSGCLFPDSQKPSNRVP } \\
\text { YPQQLRTVQDAVDAYQKDTGVLPIKTMEAD } \\
\text { TPLMERYQIELGRLIPRYMSDPPSNSFEGGGT } \\
\text { FIYLLVDVDTKPTVKLMDLLVAEELQKLQVR } \\
\text { IDAYRKKNEKYPFKGSFGKNQFTLDYKKLFI } \\
\text { KKEPTVPSPYSDEKLSIYVDGQGRLFINYLPE } \\
\text { LKKAVQTAKKKPKVGQDIRYLLYEDQPFVPA } \\
\text { YSQSYTINEKGEPVFSEESIEESEN }\end{array}$ \\
\hline
\end{tabular}


Table 3 continuous

\begin{tabular}{|c|c|c|c|c|c|c|c|c|c|}
\hline $\begin{array}{l}\text { PseudoCo } \\
\text { ntig_NC_0 } \\
10556.1\end{array}$ & peg & $\begin{array}{l}\text { PseudoCo } \\
\text { ntig_NC_0 } \\
10556.1 \_2 \\
235507 \_22 \\
35196\end{array}$ & 2235507 & 2235196 & - & $\begin{array}{l}\text { Thiored } \\
\text { oxin }\end{array}$ & $\begin{array}{l}\text { idu(2);CBSS- } \\
\text { 315749.4.peg } \\
\quad .3658 \\
\text { idu(2);Glycin } \\
\text { e_reductase, } \\
\text { sarcosine_red } \\
\text { uctase_and_b } \\
\text { etaine_reduct } \\
\quad \text { ase }\end{array}$ & $\begin{array}{l}\text { atggcaatcgtacacgcaactagccaatcatttaaagaagaaacacaagaaggactcgtcettgttgatttt } \\
\text { tgggcaacatggtgtggaccatgtcgtatgctcgcactgttcttgaagaactcgatgctgacatgcaaga } \\
\text { tgtaaaaatcgtcaaagtcgacgtagatgcaaacccagaagtagctggagcattccaagttcaaagtatc } \\
\text { ccgacactcgttctttcaaagacggacaacttgtcaacaaacaatgggcttcatgccgaaagacgcac } \\
\text { ttaaagaattcgttgaaacatctaactaa }\end{array}$ & $\begin{array}{l}\text { MAKFTIVDKDTCIACGACGAAAPDIYDYDDEG } \\
\text { LAYVILDDNNGTAEIPEALFDDMIDAFEGCPTD } \\
\text { SIKVADESFDGDALKFE }\end{array}$ \\
\hline $\begin{array}{l}\text { PseudoCo } \\
\text { ntig_NC_0 } \\
10556.1\end{array}$ & peg & $\begin{array}{l}\text { PseudoCo } \\
\text { ntig_NC_0 } \\
10556.1 \_2 \\
389480 \_23 \\
90478\end{array}$ & 2389480 & 2390478 & + & $\begin{array}{l}\text { Thiored } \\
\text { oxin } \\
\text { reductas } \\
\mathrm{e}(\mathrm{EC} \\
1.8 .1 .9)\end{array}$ & $\begin{array}{c}\text { idu(3);pyrimi } \\
\text { dine_convers } \\
\text { ions } \\
\text { idu(3);Thiore } \\
\text { doxin-disulfi } \\
\text { de_reductase } \\
\text { idu(3);Glycin } \\
\text { e_reductase, } \\
\text { sarcosine_red } \\
\text { uctase_and_b } \\
\text { etaine_reduct } \\
\text { ase }\end{array}$ & 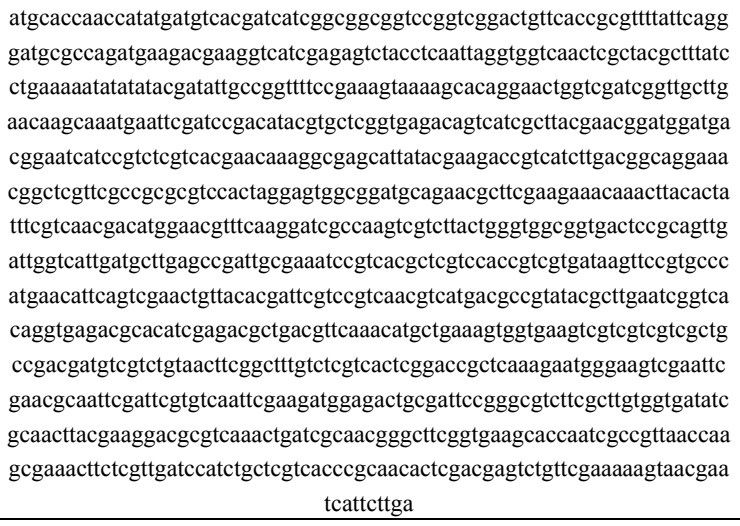 & $\begin{array}{l}\text { MAIVHATSQSFKEETQEGLVLVDFWATWCGPC } \\
\text { RMLAPVLEELDADMQDVKIVKVDVDANPEVA } \\
\text { GAFQVQSIPTLVLFKDGQPVNKTMGFMPKDAL } \\
\text { KEFVETSN }\end{array}$ \\
\hline $\begin{array}{l}\text { PseudoCo } \\
\text { ntig_NC_0 } \\
10556.1\end{array}$ & peg & $\begin{array}{l}\text { PseudoCo } \\
\text { ntig_NC_0 } \\
10556.1 \_2 \\
417640 \_24 \\
17002\end{array}$ & 2417640 & 2417002 & - & $\begin{array}{l}\text { SAM-de } \\
\text { pendent } \\
\text { methlytr } \\
\text { ansferas } \\
\text { e YrrT }\end{array}$ & $\begin{array}{l}\text { icw(2);Methi } \\
\text { onine_Biosy } \\
\text { nthesis }\end{array}$ & $\begin{array}{l}\text { atgacagtacgttttatggatgtttcacagaatgggcatcgacgtatgacgagacagtgaccggacacga } \\
\text { tccggagtataaagaggttttcgtcgatacgatgagatttggatacagtagcggataaagcgcagtcgc } \\
\text { cggtcattgaattcggagcaggcacagggaacctgacacaacgtcttctggcacgtcacgacgccgtac } \\
\text { tcgccgtcgaaccaagtccggagatgcgggcaattctgacggaaaagattccgtcacttgatgtacaaga } \\
\text { cggtcacttcctgtcgttcgaagcgaaggaagcacgcagttttgtttcgacgtatgcgtttcatcatctaaca } \\
\text { gatgaggaaaagggagaagcaatcgaactgatggcatcacatttaccggcagacggaaaaatcgtcta } \\
\text { cgcggatacgatgttcgtctcagaagaggcacgcttgcaaacgattcgtgaagcacgtgctcaagggttc } \\
\text { gacgcgttagcggaagatctcgaacgcgagttttacccattgattccagttatggaagaattgtttacagca } \\
\text { cggggattcactgttaaatttatacaatacaatcacttcgtctggctcgtagaagccgagaaaatggggga } \\
\text { ataa }\end{array}$ & $\begin{array}{c}\text { MHQPYDVTIIGGGPVGLFTAFYSGMRQMKTKV } \\
\text { IESLPQLGGQLATLYPEKYIYDIAGFPKVKAQEL } \\
\text { VDRLLEQANEFDPTYVLGETVIAYERMDDGIR } \\
\text { LVTNKGEHYTKTVILTAGNGSFAARPLGVADA } \\
\text { ERFEETNLHYFVNDMERFKDRQVVLLGGGDSA } \\
\text { VDWSLMLEPIAKSVTLVHRRDKFRAHEHSVEL } \\
\text { LHDSSVNVMTPYTLESVTGETHIETLTFKHAES } \\
\text { GEVVVVAADDVVCNFGFVSSLGPLKEWEVEFE } \\
\text { RNSIRVNSKMETAIPGVFACGDIATYEGRVKLIA } \\
\text { TGFGEAPIAVNQAKLLVDPSARHPQHSTSLFEK } \\
\text { VTNHS }\end{array}$ \\
\hline
\end{tabular}


Table 3 continuous

\begin{tabular}{|c|c|c|c|c|c|c|c|c|c|}
\hline $\begin{array}{l}\text { PseudoCo } \\
\text { ntig_NC_0 } \\
10556.1\end{array}$ & peg & $\begin{array}{l}\text { PseudoCo } \\
\text { ntig_NC_0 } \\
10556.1 \_2 \\
418462 \_24 \\
18181\end{array}$ & 2418462 & 2418181 & - & $\begin{array}{l}\text { Thiored } \\
\text { oxin }\end{array}$ & $\begin{array}{l}\text { idu(2);CBSS- } \\
\text { 315749.4.peg } \\
\quad .3658 \\
\text { idu(2);Glycin } \\
\text { e_reductase, } \\
\text { sarcosine_red } \\
\text { uctase_and_b } \\
\text { etaine_reduct } \\
\quad \text { ase }\end{array}$ & $\begin{array}{l}\text { atgcaagaggtcacgaccgtcccggaaaacgggctattgtatgtctatgcaccgatgtgcgggacat } \\
\text { gcgccatcgcggagcgtatgcttgatatcgtcgaagcaacggaatcaggtcaatcgattcagaaggc } \\
\text { gaacgggaatttcattccggatttcttagaagaagccegtgtcatgagtgttctgcgttgttgcgaattg } \\
\text { aagaaaatcaagtcgtagagcgactttatgetttccagtccgttcaaaacgtcttgctttctgtcaagaa } \\
\text { cggtaa }\end{array}$ & $\begin{array}{c}\text { MTVRFMDVFTEWASTYDETVTGHDPEYKEVFRR } \\
\text { YDEILDTVADKAQSPVIEFGAGTGNLTQRLLARH } \\
\text { DAVLAVEPSPEMRAILTEKIPSLDVQDGHFLSFEA } \\
\text { KEARSFVSTYAFHHLTDEEKGEAIELMASHLPAD } \\
\text { GKIVYADTMFVSEEARLQTIREARAQGFDALAED } \\
\text { LEREFYPLIPVMEELFTARGFTVKFIQYNHFVWLV } \\
\text { EAEKMGE }\end{array}$ \\
\hline \multirow[t]{2}{*}{$\begin{array}{l}\text { PseudoCo } \\
\text { ntig_NC_0 } \\
10556.1\end{array}$} & \multirow[t]{2}{*}{ peg } & $\begin{array}{l}\text { PseudoCo } \\
\text { ntig_NC_0 } \\
10556.1 \_2 \\
425524 \_24 \\
26171\end{array}$ & \multirow[t]{2}{*}{2425524} & \multirow[t]{2}{*}{2426171} & \multirow[t]{2}{*}{+} & \multirow[t]{2}{*}{$\begin{array}{l}\text { SAM-de } \\
\text { pendent } \\
\text { methyltr } \\
\text { ansferas } \\
\quad \text { e }\end{array}$} & & $\begin{array}{c}\text { atgagtcaaaccgagcatgtatggaatcaaaaagccgctgactgggcggatcgcgctgacgatatgt } \\
\text { ggacgaacggcagtcggaaaaccgttttgccgttcttacgaaaaacgatcaccggtggtcgtttgctt } \\
\text { gatctcggttgcggtgatggtgcagctgtcgettactgacaccggacttcagatagtcggacttgat } \\
\text { gttcagacgagatgatccggatcgcccgtgagaaatcacccgagcagacgttcatcgttggaacgg } \\
\text { gtgaagcattgccgttcgccgatcatgcgtttgatgtcgtcctcgccgtcaactcactcgaatggtcga } \\
\text { cacgtcccgttcaagtgctgcaagaaatcgaacgcgttgccccgcttgtcgtcatcagtctactcggtc } \\
\text { cgacagcagcaccacggcaacttgcttaccgtcgtctctatggtgaggaagtcgcgatgggaaatac } \\
\text { gatgatgccgtgggaactgttgcagctagcaaaagaacgaggetggacgttactcgatgaagcggt } \\
\text { catccaaaaagaaggtgccgtcatgacggggcatcggttactggatcaagcccatgccttctcatgttt } \\
\text { gtttgctttcagacgacagctgtgagggaaagataa }\end{array}$ & $\begin{array}{c}\text { MQEVTTVPENGLLYVYAPMCGTCAIAERMLDIVE } \\
\text { ATESGQSIQKANGNFIPDFLEEARVMSVPALLRIEE } \\
\text { NQVVERLYAFQSVQNVFAFCQER }\end{array}$ \\
\hline & & & & & & & & & $\begin{array}{l}\text { MNTGKVKWFNAEKGFGFIEVEGGEDVFVHFSAIT } \\
\text { GEGFKTLDEGQEVEFEITEGARGAQAANVVKL }\end{array}$ \\
\hline
\end{tabular}




\section{REFERENCES}

[1] Ahluwalia, S. S. and Goyal, D., Microbial and plant derived biomass for removal of heavy metals from wastewater. Bioresour. Technol.,98 (2007) 2243-2257.

[2] Albarracín, V., Gärtner, W., and Farias, M. E., Forged under the sun: life and art of extremophiles from Andean Lakes. Photochem. Photobiol. 1 (2016) 14-28. doi: 10.1111/php.1 2555

[3] Belifore, C., Ordonez, O.F. and Farias, M.E., Proteomic approach of adaptive response to arsenic stress in Exiguobacterium sp. S17, an extremophile strain isolated from a high-altitude Andean Lake stromatolite. Extremophiles. 17(3) (2013) pp 421-431.

[4] Borsodi, A.K., Micsinai, A., Rusznyák, A., Vladár, P., Kovács, G., Tóth, E.M., Márialigeti, K., Diversity of alkaliphilic and alkali tolerant Bacteria cultivated from Decomposing Reed Rhizomes in a Hungarian soda Lake. Microb. Ecol. 50 (2005) 9-18. http://dx.doi.org/10.1007/s0 0248-004-0063-1.

[5] Carneiro, A.R, Ramos, R.T.J., Dall'Agnol H, Pinto AC, de Castro Soares. S, Santos. A.R, Guimarães, L.C., Almeida, S.S., Baraúna, R.A. das Graças, D.A., Franco, L.C., Ali, A., Hassan, S.S., Nunes, C.I.P., Barbosa, M.S., Fiaux, K.K.,Aburjaile, F.F., Barbosa EGV, Bakhtiar, S.M., Vilela, D., Nobrega, F., dosSantos, A.L., Carepo, M.S.P., Azevedo, V., Schneider, M.P.C., Pellizari,V.H.,Silva, A., Genome sequence of Exiguobacterium antarcticum B7, Isolated from a biofilm in Ginger Lake, King George Island, Antarctica. J. Bacteriol. 194 (2012) 6689-6690. http://dx.doi.org/10.1128 /JB.01791-12.

[6] Castro-Severyn, J., Remonsellez,F.,Valenzuela, Salinas, S.L., Fortt, J., Aguilar, P., Pardo-Esté., C.,Dorador, C., Quatrini, R., Molina, F., Aguayo, D., Castro-Nallar, E. and Saavedra, C.P., Comparative Genomics Analysis of a New Exiguobacterium Strain from Salar de Huasco Reveals a Repertoire of Stress-Related Genes and Arsenic Resistance. Front. Microbiol. 8:456 (2017) doi: 10.3389/fmicb.2017.00 456

[7] Chaturvedi, P, Shivaji, S., Exiguobacterium indicumsp. nov., a psychrophilic bacterium from the Hamta glacier of the Himalayan mountain ranges of India. Int. J. Syst. Evol. Microbiol. 56 (2006) 2765-2770. http://dx.doi.org/10.1099/ ijs.0.64508-0.

[8] Chen Jian, Sun Guo, Wang Xiaoxue,Lorenzo Victor (2014) Volatilization of Arsenic from Polluted Soil by Pseudomonas putida Engineered for Expression of the arsM Arsenic(III) S-Adenosine Methyltransferase Gene. Environmental Science and Technology 48(17): 10337 10344.

[9] Chowdhury, A. M. R., Arsenic crisis in Bangladesh. Sci. Am.291 (2004) 87-91.

[10] Crapart, S, Fardeau, M.L., Cayol, J.L., Thomas, P, Sery C, Ollivier, B., Combet-Blanc, Y., Exiguobacterium profundum sp. nov., a moderately thermophilic, lactic acid-producing bacterium isolated from a deep sea hydrothermal vent. Int.
J. Syst. Evol. Microbiol.57 (2007) 287-292. http://dx.doi.or g/10.1099/ijs.0.64639-0.

[11] Cullen, W. R. and Reimer, K. J., Arsenic speciation in the environment. Chem. Rev. 89 (1989) 713-764.

[12] Daware, V. and Gade, W., 2015. Mechanism of Arsenic Tolerance in Klebsiella pneumonia (HQ857583). International Journal of Microbiology and Applied Sciences ISSN: 2319-7706 Volume 4 Number 11 (2015) pp. 457-469.

[13] De J., Ramaiah N., Vardanyan L. 2008.Detoxification of toxic heavy metals by marine bacteria highly resistant to mercury. Mar. Biotechnol., 10(4):471 477.

[14] Felsenstein, J., Confidence limits on phylogenies: An approach using the bootstrap. Evolution 39 (1985) 783-791.

[15] Hughes, M. F., Arsenic toxicity and potential mechanisms of action. Toxicol. Lett.,133 (2002) 1-16.

[16] Kashama, J., Prince, V., Simao-Beaunoir., A.M. and Beaulieu, C., Carbon utilization profiles of bacteria colonizing the head box water of two paper machines in a Canadian mill. J. Ind. Microbiol. Biotechnol. 36 (2009) 391399.http://dx.doi.org/10.1007/s10295-008-0509-4.

[17] Kimura, M., A simple method for estimating evolutionary rate of base substitutions through comparative studies of nucleotide sequences. Journal of Molecular Evolution 16 (1980) 111-120.

[18] Kumar, S., Stecher, G., and Tamura K., MEGA7: Molecular Evolutionary Genetics Analysis version 7.0 for bigger datasets. Molecular Biology and Evolution (submitted) (2015).

[19] Kunitsky, C., Osterhout, G., and Sasser, M., Identification of microorganisms using fatty acid methyl ester (FAME) analysis and the MIDI Sherlock Microbial Identification System. Encyclopedia of Rapid Microbiological Methods. MIDI, Inc., Newark, DE (2005).

[20] Mehrag, A. A. and Rahman, M. M., Arsenic contamination of Bangladesh paddy field soils: implications for rice contribution to arsenic consumption. Environ Sci Technol. 37 (2003) 229-234.

[21] Nourbakhsh, M., Sag, Y., Ozer, D., Aksu, Z., Kutsal, T. And Calgar, A., A comparative study of various biosorbents for removal of chromium (VI) ions from industrial wastewater. Process Biochem.,29 (1994) 1-5.

[22] Oyedara, O.O., Segura-Cabrera, A., Guo ,X., Elufisan , T.O., González, R.A.C and Pérez, M.A.R. Whole-Genome Sequencing and Comparative Genome Analysis Provided Insight into the Predatory Features and Genetic Diversity of Two Bdellovibrio Species Isolated from Soil. Hindawi International Journal of Genomics. Volume (2018), Article ID 9402073, 10pageshttps://doi.org/10.1155/2018/9402073.

[23] Pandey, N. and Bhatt, R., Arsenic Removal and Biotransformation Potential of Exiguobacterium Isolated from an Arsenic-Rich Soil of Chattisgarh, India. Clean Soil, Air and Water (2015).

[24] Paul, D., Kazy, S.K., Gupta, A.K., Pal, T. and Sar, P., 2015. Diversity, Metabolic Properties and Arsenic Mobilization Potential of Indigenous Bacteria in Arsenic Contaminated Groundwater of West Bengal, India. PLoS ONE 10(3): e0118735. doi: 10.1371/journal.pone.0118735, pp 1-40. 
[25] Rebollar, E. A., Avitia, M., Eguiarte, L., González-González, A., Mora, L., Bonilla-Rosso, G. Y., Water-sediment niche differentiation in ancient marine lineages of Exiguobacterium endemic to the CuatroCienegas Basin. Environ. Microbiol. 14 (2012) 2323-2333. doi:10.1111/j.14 62-2920.2012.02784.x

[26] Sacheti, P., Bhonsle, H., Patil, R., Kulkarni, M.J., Srikanth, R. and Gade, W., Arsenomics of Exiguobacterium sp. PS (NCIM 5463). Issue 25 (2013).

[27] Shi, H., Shi, X. And Liu, K-J. Oxidative mechanisms of arsenic toxicity and carcinogenesis. Mol. Cell. Biochem., 255 (2004) 67-78.

[28] Smith, A.H., Lopipero, P.A., Bates, M.N. and Steinmaus, C.M., Public health. arsenic epidemiology and drinking water standards. Science,296 (2002) 2145-2146.

[29] Stiefel. P., Schneider. J., Amberg. C., Maniura-Weber. K. and Ren. Q., A simple and rapid method for optical visualization and quantification of bacteria on textiles. Scientific Reports. 6 (2016) 39635 pp 1-9. DOI: 10.1038/srep39635

[30] Tang, J., Zhang, Y., Meng, H., Xue, Z., and Ma, J., Complete genome sequence of Exiguobacteriumsp. Strain MH3, isolated from rhizosphere of Lemna minor. Genome
Announc. 1(6) (2013) e01059-13.http://dx.doi.org/10.1128/ genomeA.01059-13.

[31] Tsuchiya, T., Ehara, A., Kasahara, Y., Hamamura, N., Amachia, S. Expression of Genes and Proteins Involved in Arsenic Respiration and Resistance in Dissimilatory Arsenate-Reducing Geobacter sp. Strain OR-1. Applied and Environmental Microbiology, 85:14 (2019), pp 1-15.

[32] USEPA, SW 846: Method 3050B - Acid Digestion of Sediments, Sludge and Soils, Rev. 2 (1996).

[33] Vishnivetskaya, T.A, Kathariou, S., Tiedje, J.M., The Exiguobacteriumgenus: biodiversity and biogeography. Extremophiles 13 (2009) 541-555. http://dx.doi.org/10.100 7/s00792-009-0243-5.

[34] Wackett, L.P., Dodge, A.G., Ellis LB., Microbial genomics and the periodic table. Appl Environ Microbiol. 70 (2004) $647-655$.

[35] Wang, T. S., Hsu, T. Y., Chung, C. H., Wang, A. S., Bau, D. T. And Jan, K. Y., Arsenite induces oxidative DNA adducts and DNA-protein cross-links in mammalian cells. Free Radical Biol. Med., 31 (2001) 321-330.

[36] Wang R-Y, Hsu Y-L, Chang L-F, Jiang S-J (2007) Anal Chim Acta 590:239-244. 